\title{
Individual Investors' Dividend Taxes and Corporate Payout Policies
}

\author{
Oliver Zhen Li, Hang Liu, Chenkai Ni, and Kangtao Ye*
}

\begin{abstract}
The 2012 Dividend Tax Reform in China ties individual investors' dividend tax rates to the length of their shareholding period. We find that firms facing a reduction (increase) in their individual investors' dividend tax rates are more (less) likely to increase dividend payout. Such an effect is concentrated in firms where incentives of controlling shareholders and minority shareholders are aligned. Furthermore, investors respond to this tax law change by reducing trading activities before the cum-dividend day and successfully lower their dividend tax penalty. Overall, our evidence enhances the notion that individual investors' tax profiles shape firms' payout policies.
\end{abstract}

\section{Introduction}

Do individual investors' dividend taxes affect firms' payout policies? This question is important, as it has implications for capital allocation efficiency (Chetty and Saez (2005), Hanlon and Hoopes (2014)). However, evidence in the current literature remains inconclusive. One stream of literature suggests that firms, in response to or in anticipation of a change in individual investors' dividend tax, alter their payout policies in a manner that is consistent with shareholders' tax preferences (Lie and Lie (1999), Chetty and Saez (2005), and Blouin, Raedy, and Shackelford (2011)). Contrary to this view, a survey of corporate executives suggests that managers of publicly listed firms in the United States view taxes as second order in shaping firms' payout policies (Brav, Graham, Harvey,

*Li, bizzhenl@nus.edu.sg, NUS Business School; Liu (corresponding author), liuhang@dufe.edu .cn, School of Accountancy, Dongbei University of Finance and Economics; Ni, nichenkai@ fudan.edu .cn, School of Management, Fudan University; and Ye, yekangtao@rbs.org.cn, School of Business, Renmin University of China. We thank Paul Malatesta (the editor), an anonymous referee, and seminar participants at Peking University, Renmin University of China, the 2014 China Finance and Accounting Conference at Xiamen, and the 2014 World Finance \& Banking Symposium at Singapore for helpful comments. Li acknowledges a Tier 2 grant (MOE2012-T2-1-035) from the Ministry of Education of Singapore. Liu acknowledges financial support from the National Nature Science Foundation of China (Grant Number 71402017) and China Internal Control Research Center. Ni acknowledges financial support from the National Nature Science Foundation of China (Grant Number 71502171). Ye acknowledges financial support from the National Nature Science Foundation of China (Grant Nos. 71072145 and 71432008). 
and Michaely (2008)). Lending support to this view, several empirical studies demonstrate that the change in firms' dividend payout around the Jobs and Growth Tax Relief Reconciliation Act of 2003 (JGTRRA) is not necessarily tax-driven (Julio and Ikenberry (2005), Edgerton (2013), and Floyd, Li, and Skinner (2015)).

We address this research question by using a recent quasi-experiment in China. Specifically, the Dividend Tax Reform of 2012 mandates that individual investors' dividend tax rates vary with the length of their shareholding periods. The rate equals $20 \%$ if shares have been held shorter than or equal to 1 month, $10 \%$ if shares have been held longer than 1 month and shorter than or equal to 1 year, and 5\% if shares have been held longer than 1 year. Before the reform, a dividend tax rate of $10 \%$ applied homogeneously to individual investors.

Employing a China setting to examine the effect of dividend taxes on corporate payout policies has the following merits. First, as individual investors dominate the trading sphere of China's equity market, the reform offers an opportunity to examine the research question in a setting where individual investors are more likely to be marginal investors. Although the JGTRRA in the United States also focuses on individuals' tax rate change, institutional investors are of considerable importance in the U.S. equity market. As such, firms' responsiveness to individual investors' tax rate change is less detectable. This complication potentially generates debate on whether individual investors' tax preferences matter when managers determine their firms' payout policies.

Second, our setting is unique in that it allows us to better address confounding factors through our identification strategy. Studies of the JGTRRA favoring a tax view have been criticized for their inability to rule out events that are contemporaneous with the enactment of the act, such as an increase in profitability of U.S. publicly listed firms and some high-profile corporate scandals that increase investors' demand for dividends (Edgerton (2013)). Indeed, Chetty and Saez ((2005), p. 816) emphasize that "future tax changes might allow identification of tax effects in an environment where such scandals are less relevant." The Dividend Tax Reform of 2012 in China increases or decreases individual investors' dividend tax rates, depending on the length of their shareholding periods. An identification strategy that uses a proxy for investors' shareholding periods thus allows us to conduct a difference-in-differences analysis in an effort to establish a causal association between individuals' dividend taxes and corporate payout policies. Such an empirical methodology is less likely to be contaminated by concurrent events.

For a sample of 1,964 firms, we obtain information on their annual dividend payments immediately before and after the dividend tax reform. We employ a difference-in-differences identification strategy by proxying for the length of investors' shareholding periods using share turnover during the year before dividend announcements. ${ }^{1}$ Measuring firms' dividend policies using dividend yield, we find that low-share-turnover firms, which likely see a reduction in their investors' dividend tax rates, are more likely to increase their dividend payouts after the reform compared to high-share-turnover firms. The change in dividend yield

\footnotetext{
${ }^{1}$ Higher share turnover indicates that investors are trading more actively and therefore have a shorter investing horizon.
} 
is economically significant. For two firms at the first and third share turnover quartiles, respectively, the difference between their changes in dividend yield around the reform is $10.5 \%$ of the sample median of dividend yield. Such a finding is robust to a change analysis specification, an alternative proxy for the length of individual investors' shareholding periods, and alternative measures of dividend payout. Our empirical results support the argument that in a setting where individual investors are of considerable importance, their dividend preferences affect corporate payout policies.

We then incorporate an agency view and examine whether tax-motivated changes in dividend policy vary with the extent of a firm's agency conflict between its controlling shareholder and minority shareholders. As controlling shareholders have the incentive and ability to appropriate corporate resources at the expense of minority shareholders, a larger deviation in incentives between these two groups implies that controlling shareholders prefer to retain rather than distribute earnings to pursue private benefits (Shleifer and Vishny (1997), Dyck and Zingales (2004), and Jiang, Lee, and Yue (2010)). Therefore, for these firms, corporate payout is less sensitive to individual investors' dividend tax rate changes. Measuring the extent of agency conflict by the divergence between controlling shareholders' voting and cash-flow rights (Claessens, Djankov, Fan, and Lang (2002), Masulis, Wang, and Xie (2009)), we find that the impact of the reform is concentrated in firms with no such divergence. Subsequent analyses using information on firms' related-party transactions and intercorporate loans further suggest that controlling shareholders' expropriation activities weaken the response of corporate payout to the dividend tax rate change, consistent with an agency perspective.

These findings on the impact of the dividend tax reform on corporate payout are predicated on the assumption that dividend tax is of significant importance to investors. An interesting feature of the reform provides us with the opportunity to assess the validity of this assumption through examining investors' trading activities. Specifically, the dividend announcement day generally precedes the cum-dividend day by approximately 70 days. As such, investors can adjust their trading activities between the dividend announcement day and the cum-dividend day to manage their dividend tax rates. There is a sufficient economic incentive for investors to adjust their trading activities, as holding shares for more than 1 month reduces their dividend tax rate from $20 \%$ to $10 \%$. We find that for highdividend-yield firms, investors reduce their trading activities during the month before the cum-dividend day. ${ }^{2}$ A further analysis of firms' ex-dividend day stock returns demonstrates that investors, by doing so, are successful in reducing their dividend tax penalties. These findings speak to the importance of dividend taxes in affecting investors' wealth, justifying firms' response to the dividend tax reform.

Our study contributes to the literature on investors' tax preferences and firms' payout policies by providing evidence on whether and how firms adapt their payout policies to cater to individual investors' tax preferences. Prior studies employing the JGTRRA setting produce mixed evidence because of the presence of

\footnotetext{
${ }^{2}$ In subsequent analysis, we also show that some investors continue to hold shares obtained shortly before the cum-dividend day to lower their dividend tax rates. However, such an effect appears to be less pronounced compared to investors' reduced share turnover before the cum-dividend day.
} 
potential nontax confounding factors (Chetty and Saez (2005), Julio and Ikenberry (2005), and Edgerton (2013)). Using a quasi-experiment in a setting where individual investors are dominant, we document that individual investors' dividend taxes affect firms' payout policies.

In addition, we show that the incentive deviation between a firm's controlling shareholder and minority shareholders can affect the responsiveness of the firm's payout policy to the tax rate change. Such a finding provides support for the notion that in a situation where concentrated ownership is the norm, controlling shareholders' distorted incentive can constitute significant friction in corporate adjustment to maximize minority shareholders' wealth. It also complements a prior study that shows that the manager-shareholder conflict can affect how payout policies respond to tax-rate changes in the United States, where a dispersed ownership structure is the norm (Brown, Liang, and Weisbenner (2007)).

The balance of the article proceeds as follows: Section II describes the institutional background of the Dividend Tax Reform of 2012 in China. Section III discusses the literature and develops hypotheses. Section IV describes sample formation. Section V presents our identification strategies and main empirical results. Section VI conducts robustness analyses. Section VII concludes.

\section{Institutional Background}

As in many countries, capital gains of individual investors are not taxed in China. However, the tax rate imposed on dividends has experienced changes in several recent reforms. Before June 13, 2005, the dividend tax rate was $20 \%$. After that, the rate was reduced to $10 \% .^{3}$ On Nov. 16, 2012, China's Ministry of Finance, the State Administration of Taxation, and the China Securities Regulatory Commission (CSRC) jointly announced that dividends would be differentially taxed, depending on the length of investors' shareholding periods. The reform mandated that dividends would be taxed at $20 \%$ if the shareholding period is shorter than or equal to 1 month, at $10 \%$ if the shareholding period is longer than 1 month and shorter than or equal to 1 year, and at $5 \%$ if the shareholding period is longer than 1 year. ${ }^{4}$

The 2012 Dividend Tax Reform in China is designed to encourage long-term investment and to restrain individual investors' short-term speculative activities. China's capital market is notoriously characterized by excessive speculative trading and a disproportionate percentage of short-term investors. Statistics provided

\footnotetext{
${ }^{3}$ The 2005 reform, compared to the 2012 reform illustrated in detail, is less ideal for examining our research question because of the existence of concurrent reforms on firms' dividend payouts. In particular, on Dec. 7, 2004, the CSRC issued rules mandating that firms can issue new shares, convertible debt, or rights offerings only if they have distributed cash dividends in the previous 3 years. On May 6, 2006, the rules were further revised, requiring firms to distribute at least $20 \%$ of the average distributable earnings in the previous 3 years before issuing securities in the public market.

${ }^{4}$ After the dividend tax reform, the levying practice of dividend tax is to impose a $5 \%$ dividend tax rate on all individual investors when firms pay dividends. Subsequently, because investors differ in their shareholding periods, an incremental dividend tax rate computed according to rules of the 2012 dividend tax reform is further imposed when investors sell shares. The incremental dividend tax rate equals $15 \%(20 \%-5 \%)$ if the holding period is shorter than or equal to 1 month, $5 \%(10 \%-5 \%)$ if the holding period is longer than 1 month and shorter than or equal to 1 year, and $0 \%(5 \%-5 \%)$ if the holding period is longer than 1 year.
} 
by the Wind database reveal that in the year before the dividend tax reform, the average share turnover (the number of shares traded deflated by the number of shares outstanding during a year) of A-share firms exceeds $400 \%$. Furthermore, a survey conducted by the China Securities Investors Protection Fund shows that only $30.92 \%$ of A-share investors hold their stocks for more than 3 months. A majority of investors enter the market simply to benefit from speculative trading.

Such a feature hinders capital market development because of a loss of mechanisms, such as price discovery. It has thus become a key agenda of the CSRC to transform China's capital market from a "speculative market" into an "investment market," particularly after Shuqing Guo was appointed as the president of the CSRC in Oct. 2011. On Dec. 1, 2011, Guo publicized his capital reform philosophy for the first time as the president of the CSRC. He specifically pointed out the lack of long-term investment and value investment in China, and encouraged more participation of shareholders with longer investing horizons. The dividend tax reform in 2012 was one such step. The CSRC stated: "The [dividend tax] reform is aimed at utilizing tax benefits to encourage long-term investment, reduce short-term speculations, and ultimately stimulate a stable capital market development" (http://www.csrc.gov.cn/pub/newsite/zjhxwfb/xwdd/201211/t2 0121116_216984.html).

This design for dividend taxation is unique in the world. Under the new tax regime, investors holding a firm's shares for a longer period benefit more from the dividends received. Note that an investor's holding period is defined as the period between the day on which the shares are purchased and the day on which the shares are sold. ${ }^{5}$ The reform, applying to individual investors, became effective Jan. 1, 2013.

The Dividend Tax Reform of 2012 in China provides us with an ideal setting to examine the importance of individual investors' tax preferences in shaping firms' payout policies. Unlike the U.S. capital market, where institutional investors are of considerable importance, China's capital market is characterized by a dominance of individual investors. The report "An Analysis of the Structure and Behaviors of Investors in the Shenzhen Stock Exchange," issued in 2012 by the Shenzhen Stock Exchange Investor Education Center, shows that individual investors' trading volume represents more than $80 \%$ of the total volume from 2007 to 2011. In addition, the Shanghai Stock Exchange Annual Statistics 2011 (2012) reveals that individual investors' trading volume accounts for $83.52 \%(80.78 \%)$ of the total. Such a feature of China's capital market, in combination with the Dividend Tax Reform of 2012, provides a powerful setting to examine firms' responsiveness in adjusting their dividend policies to changes in individual investors' dividend tax preferences. ${ }^{6}$

\footnotetext{
${ }^{5}$ Ideally, we need to pinpoint the date of a future sale to determine investors' dividend tax rate. For research design purpose, we rely on investors' trading activities before the dividend announcement days to proxy investors' holding periods.

${ }^{6}$ Serving as an alternative mechanism to return capital to investors, share repurchases can act as a substitute for dividend payments. However, analyzing repurchases is not meaningful in our setting for the following reasons. First, repurchases rarely occur in China's capital market. During the 20 years between the establishment of China's capital market and 2012, public firms in China announced a total of 171 share repurchases, fewer than 10 a year, on average. Second, even if there are repurchases, they
} 


\section{Hypotheses Development}

\section{A. Investors' Tax Preferences and Corporate Payout Policies}

According to Miller and Modigliani (1961), a firm's dividend policy is irrelevant for its value. In a so-called perfect market, retained earnings and dividends are equally preferred by shareholders. However, such a theory builds on several restrictive and perhaps unrealistic assumptions, one of which is the absence of taxes at either the corporate level or the personal level. ${ }^{7}$ Subsequent research introduces capital market imperfections into Miller and Modigliani. Notably, taxes are viewed as a matter of considerable importance (Graham (2003)), as the double taxation of dividends represents a significant cost to shareholders. Therefore, firms' dividend policies are considered to be associated with investors' tax preferences.

An extensive stream of the literature investigates the "dividend tax clientele" (i.e., the association between institutional ownership and dividend payout). Such institutions as pensions and university endowments, among others, have significantly lower tax rates compared to those of individual investors in the United States. Therefore, they prefer that firms pay more dividends. However, empirical evidence on this link is inconclusive (Michaely, Thaler, and Womack (1995), Del Guercio (1996), Dhaliwal, Erickson, and Trezevant (1999), and Grinstein and Michaely (2005)). In a more recent study, Desai and Jin (2011) consider the tax heterogeneity of various institutions and show that firms with high dividend payouts are held more by institutional investors with low dividend tax rates. Despite the focus on institutions' tax profiles in this stream of the literature, the picture is incomplete without looking into individual investors' tax profiles.

The JGTRRA represents an opportunity to examine how individual investors' tax rates affect firms' dividend policies. Chetty and Saez (2005) find that firms significantly increase their probabilities of dividend initiations after the enactment. Likewise, Blouin et al. (2011) demonstrate that the ratio of dividend payout to total payout increases after the reform. Evidence from these studies is thus consistent with the view that firms alter their payout policies in a manner consistent with individual investors' tax preferences. However, another stream of the literature casts doubt on attributing payout policies to the tax factor (Julio and Ikenberry (2005), Edgerton (2013), and Floyd et al. (2015)). In particular, Edgerton (2013) suggests that an increase in dividend payout after the JGTRRA can be caused by firms' increasing profitability or investors' heightened demand for dividends after observing high-profile corporate scandals, such as Enron and WorldCom. This calls into question whether the surge in dividend payouts around the enactment of JGTRRA is due to a reduction in individual investors' tax rates.

The Dividend Tax Reform of 2012 in China provides us with a quasiexperiment to examine whether firms alter their dividend policies in response to a change in individual investors' tax rates. With firms differentially affected by the reform, depending on the length of their investors' shareholding periods,

primarily serve the purpose of adjusting the ownership structure or catering to firms' equity incentive plans instead of returning capital to investors.

${ }^{7}$ Miller and Modigliani (1961) make three assumptions: i) perfect capital markets, ii) rational behaviors, and iii) perfect certainty. 
identification through proxying for the length of shareholding period allows us to filter out confounding events and attribute the effect, if any, to taxes. In addition, the dominant role played by individual investors trading in China's equity market renders such an investigation more pertinent to the research question. Ultimately, the responsiveness of firms' payout policies to individuals' tax rates is a function of the importance of individuals as shareholders (Perez-Gonzalez (2003), Moser (2007), and Jacob and Jacob (2013)). Based on this tax reform, when investors hold their shares for a longer (shorter) period, they face a lower (higher) dividend tax rate. Firms are therefore expected to increase (decrease) dividend payouts accordingly. We propose our first hypothesis:

Hypothesis 1. Firms whose individual investors have long shareholding periods are more likely to increase dividend payouts after the tax reform, compared to firms whose individual investors have short shareholding periods.

\section{B. Agency Cost}

The conceptual framework above is based on a key assumption that corporate decision makers are working in the best interests of shareholders. However, there often exists an agency conflict between a firm's controlling shareholder and its minority shareholders.

La Porta, Lopez-de-Silanes, and Shleifer (1999) show that the Berle and Means (1932)-type firms with dispersed ownership are rare outside rich commonlaw countries such as the United States. In most economies, particularly those that are less developed, concentrated ownership is the norm. Corporations with such an ownership structure are less affected by the traditional manager-shareholder agency conflict modeled in Jensen and Meckling (1976). Instead, the prevailing agency conflict is between the controlling shareholder and minority shareholders (Grossman and Hart (1988)).

As Shleifer and Vishny (1997) point out, when ownership gets beyond a certain point, large shareholders gain enough control and are more prone to pursue private benefits at the expense of minority shareholders. Controlling shareholders can siphon off resources through related-party transactions, intercorporate loans, cash reserves, or value-destroying investments (Cheung, Rau, and Stouraitis (2006), Masulis et al. (2009), and Jiang et al. (2010)). This within-shareholders agency conflict potentially reduces the sensitivity of corporate payouts to individual investors' dividend taxes because, rather than distributing the cash evenly to all shareholders, controlling shareholders can choose to retain the cash and pursue private benefits (Faccio, Lang, and Young (2001)). The arguments above generate the following hypothesis:

Hypothesis 2. The impact of the dividend tax reform on firms' dividend policies is more pronounced in firms where the interests of controlling shareholders and minority shareholders are aligned.

\section{Investors' Responsiveness}

For individual investors' tax preferences to be relevant to managers' decision making, a premise is that dividend taxes are of considerable importance to investors. The prior literature has provided evidence on whether ownership structure shifts when firms change their payout policies or whether investors are 
attracted to firms based on their differential tax preferences (Michaely et al. (1995), Dhaliwal et al. (1999), and Desai and Jin (2011)). Empirical evidence in these studies does not offer a conclusive answer. We test it directly using a unique feature of our setting.

Specifically, there is, on average, a 70-day gap between the dividend announcement day and the cum-dividend day in our sample. As the length of an investor's shareholding period, and hence his or her dividend tax rate, is determined on the day the shares are sold, trading activities during this window potentially affect the investor's tax rate and hence the after-tax wealth stemming from dividends received. As the dividend announcement day strictly precedes the cum-dividend day, a firm's dividend policy can be taken as given by the time an investor approaches the cum-dividend day. If individual investors consider the dividend tax to be important, they will reduce their trading activities during this period to avoid a higher tax rate (from $20 \%$ to $10 \%$ ), particularly in firms paying high dividends. We propose our third hypothesis:

Hypothesis 3. Average share turnover during the month before the cum-dividend day decreases after the tax reform in firms with high dividend yields, compared to that of firms with low dividend yields.

\section{Stock Returns on the Ex-Dividend Day}

To determine whether investors successfully reduce their dividend tax penalties by managing their shareholding periods, we examine firms' stock return patterns on ex-dividend days. Such an analysis provides us information on a firm's marginal investor's dividend tax status. We provide a parsimonious model to illustrate why stock prices around ex-dividend days should reflect the marginal investor's dividend tax rate.

For an investor to be indifferent regarding selling a share on the cumdividend day or on the ex-dividend day (Elton and Gruber (1970), Graham, Michaely, and Roberts (2003)), we need to have the following condition:

(1) $P_{\mathrm{CUM}}-t_{\mathrm{CG}} \times\left(P_{\mathrm{CUM}}-P_{\mathrm{BASIS}}\right)=P_{\mathrm{EX}}-t_{\mathrm{CG}} \times\left(P_{\mathrm{EX}}-P_{\mathrm{BASIS}}\right)+D \times\left(1-t_{\mathrm{DIV}}\right)$,

where $P_{\mathrm{BASIS}}$ is the price of a share when it is purchased, $P_{\mathrm{CUM}}$ is the price of a share on the cum-dividend day, $P_{\mathrm{Ex}}$ is the price of a share on the ex-dividend day, $t_{\mathrm{DIV}}$ is the dividend tax rate, $t_{\mathrm{CG}}$ is the capital gain tax rate, and $D$ is the dividend per share.

Equation (1) can be simplified to

$$
P_{\mathrm{CUM}}-P_{\mathrm{EX}}=\left[\left(1-t_{\mathrm{DIV}}\right) /\left(1-t_{\mathrm{CG}}\right)\right] \times D .
$$

As capital gain tax rate $t_{\mathrm{CG}}$ is 0 in our setting, we have

$$
\left(P_{\mathrm{CUM}}-P_{\mathrm{EX}}\right) / P_{\mathrm{CUM}}=\left(1-t_{\mathrm{DIV}}\right) \times\left(D / P_{\mathrm{CUM}}\right),
$$

which can be turned into

$$
\left(P_{\mathrm{EX}}+D-P_{\mathrm{CUM}}\right) / P_{\mathrm{CUM}}=t_{\mathrm{DIV}} \times\left(D / P_{\mathrm{CUM}}\right) .
$$

Equation (4) suggests that the ex-dividend day excess return can be modeled as a function of the marginal investor's dividend tax rate $\left(t_{\mathrm{DIV}}\right)$ and dividend 
yield $\left(D / P_{\mathrm{CUM}}\right)$. Hence, the association between the ex-dividend day return and the dividend yield (dividend tax penalty) is an estimate of $t_{\mathrm{DIV}}$. After the dividend tax reform, the association becomes more pronounced for firms with high share turnover during the month before the cum-dividend day. Therefore, we propose our fourth hypothesis:

Hypothesis 4. The association between the ex-dividend day excess stock return and dividend yield increases after the tax reform for firms with high share turnover during the month before the cum-dividend day, compared to that of firms with low share turnover during the month before the cum-dividend day.

\section{Sample}

We obtain our empirical sample from the China Stock Market and Accounting Research (CSMAR) database. Our analyses are divided into three parts: i) an analysis of firms' dividend policies around the reform, ii) an analysis of investors' trading activities before the cum-dividend days, and iii) an analysis of stock returns on ex-dividend days. As the latter two parts require firms to have nonzero cash dividends, their samples are different from the sample employed in the first part. We thus describe their sample selection processes separately.

The Dividend Tax Reform of 2012 in China was signed into law Nov. 16, 2012 and became effective Jan. $1,2013 .{ }^{8}$ We consider only annual dividend payments as quarterly dividend payments; other special dividend payments are rare in China. ${ }^{9}$ We begin with a sample consisting of 5,026 observations for all A-share firms in 2012 and 2013. This 2-year period is chosen because it contains 1 year before and 1 year after the reform to facilitate a difference-in-differences identification strategy. Such a choice also addresses the concern raised in Bertrand, Duflo, and Mullainathan (2004) that an empirical sample containing multiple years before or after an event (dividend tax reform in our context) can result in inconsistent standard errors when employing a difference-in-differences specification. ${ }^{10} \mathrm{We}$ then apply the following filters to this sample. First, we exclude 81 observations in the financial industry. Second, we exclude firms lacking historical dividend payment information to construct our dividend initiation and dividend omission variables. This step eliminates 477 observations. Third, we omit 636 observations due to missing values for variables required in the empirical analyses. The final sample for our dividend policy analysis comprises 3,832 observations representing 1,964 unique firms. There are 1,882 (1,950) observations in 2012 (2013). ${ }^{11}$

For our analyses of investors' trading activities and ex-dividend stock returns, we first identify 2,589 observations for firms issuing annual cash dividends, but not stock dividends, quarterly dividends, or special dividends, in 2012 and 2013. We further delete 56 observations in which the interval between

\footnotetext{
${ }^{8}$ For all public firms in China, the calendar year serves as the fiscal year.

${ }^{9}$ During our sample period of 2012 to 2013 , the proportion of firms paying quarterly dividends and special dividends is $4.39 \%$.

${ }^{10}$ In untabulated analysis, we enlarge our empirical sample to cover 2006 to 2013. Starting in 2006 ensures a clean prereform period, as the previous significant tax reform occurred in June 2005. Our inference remains.

${ }^{11}$ Our empirical results are qualitatively unchanged if we employ a balanced panel.
} 
a firm's dividend announcement day and its cum-dividend day is shorter than 1 month, 71 observations for firms in the financial industry, and 254 observations with missing values for variables required in the empirical analyses. This sampleselection process leaves us with 998 (1,210) observations in 2012 (2013), totaling 2,208 firm-year observations. The Appendix describes our sample-selection process.

\section{Empirical Results}

\section{A. Descriptive Statistics}

To maintain consistency with prior studies (Grinstein and Michaely (2005), Desai and Jin (2011)), we measure a firm's payout policy by its dividend yield, YIELD. It is defined as annual cash dividends scaled by market capitalization at the previous fiscal year-end. ${ }^{12}$ To eliminate the influence of outliers, we winsorize all continuous variables at the $1 \%$ and $99 \%$ levels. We present in Panel A of Table 1 descriptive statistics of key variables used in our empirical analyses. Panel B shows the breakdown of our sample firms by industry distribution. We also tabulate the industry average of firms' dividend yields. Among all industries, the transportation industry emerges as having the highest dividend yields.

Before proceeding to regression analyses, we present a graphic illustration of the difference between the pattern of dividend policies of firms with long-horizon individual investors and that of firms with short-horizon individual investors. We expect the former to increase their dividend payouts relative to the latter after the reform.

We plot the patterns of firms' dividend yields from 2006 through 2013 in Figure $1 .{ }^{13} \mathrm{We}$ categorize firms into two groups based on the average daily share turnover during the year before the announcement dates of 2012 dividends, multiplied by -1 (HP). HP serves as our proxy for the length of individual investors' average shareholding periods, with a higher value indicating a longer shareholding period. We then construct and plot the annual average of YIELD for each subsample. Specifically, Figure 1 suggests that, compared to firms whose individual investors have short holding periods (low-HP firms), firms whose individual investors have long holding periods (high-HP firms) increase their dividend yields after the dividend tax reform. In addition, when comparing average dividend yields before the reform, we find that the two lines are approximately parallel, particularly so during the year preceding the reform. Such a prereform pattern suggests that the reform is largely unanticipated by the capital market.

\footnotetext{
${ }^{12}$ In robustness tests, we repeat our main analyses using four alternative measures of a firm's dividend policy: i) annual cash dividends deflated by net income, ii) annual cash dividends deflated by total assets, iii) dividend initiations, and iv) dividend omissions. Our inference remains.

${ }^{13}$ Starting in 2006 serves the following purposes: First, it depicts a longer time series of firms' dividend yields before the reform, thus helping us evaluate whether firms anticipate the reform; second, it ensures that there is no other tax regime change in this sample period, as the previous tax reform occurred in June 2005.
} 


\section{B. Dividend Policies around the Reform}

To determine whether managers alter firms' payout policies when individual investors' dividend tax rates change, we employ a difference-in-differences specification where we compare the change in dividend payout for firms whose individual investors have long holding periods with that of firms whose individual investors have short holding periods. To achieve this, we require a variable that measures the length of investors' holding periods, as it determines the change in individual investors' dividend tax rates. We construct a proxy using a firm's

\section{TABLE 1 \\ Summary Statistics}

Panel A of Table 1 presents summary statistics of key variables used in the empirical analyses. Our sample comprises 3,832 firm-year observations for 2012 and 2013. Panel B shows the industry distribution of sample firms and the industry average of dividend yield (YIELD). YIELD is defined as annual cash dividends scaled by market capitalization at the previous fiscal year-end. EVENT is an indicator that equals 1 for 2013 (postreform), and 0 for 2012 (prereform). HP is defined as the average daily share turnover during the year before the dividend announcement dates, multiplied by -1 . In(MCAP) is defined as the natural logarithm of a firms' market capitalization at the previous fiscal year-end. LEV is defined as total liabilities divided by total assets at the previous fiscal year-end. MB is defined as the market value of equity divided by book value of equity at the previous fiscal year-end. ROE is defined as net income during the previous fiscal year divided by book value of equity at the previous fiscal year-end. FCF is defined as operating income before interest expense and noncash payment (e.g., depreciation, amortization) minus capital expenditures during the previous year, divided by total assets at the previous fiscal year-end. CASH is defined as cash divided by total assets at the previous fiscal year-end. VOLATILITY is defined as the standard deviation of monthly returns during the previous fiscal year. RETURN is defined as the stock return during the previous fiscal year. SOE is an indicator that equals 1 if the controlling shareholder of a firm is a government entity, and 0 otherwise. TOP1 is defined as the percentage of shares held by the largest shareholder at the previous fiscal year-end. TURNOVER is defined as the average daily turnover in the 1 month before the cum-dividend day. ABTURNOVER is defined as the difference between TURNOVER and NTURNOVER, where NTURNOVER is measured as average daily turnover in the 60 days before the date of the dividend tax reform (Nov. 16, 2012). RET EX is defined as stock return minus expected return constructed from the market model. YIELD_ANN is defined as annual cash dividends scaled by market capitalization on the dividend announcement day. YIELD_CUM is defined as annual cash dividends scaled by market capitalization on the cum-dividend day. RISK 1 is defined as the standard deviation of firm-specific stock returns during the 60-day period preceding the date of the dividend tax reform (Nov. 16, 2012), scaled by the standard deviation of market returns over the same period. BETA1 is defined as the firmspecific market model beta estimated over the 60-day period preceding the dividend tax reform date. RISK2 is defined as the standard deviation of firm-specific stock returns over the 80 trading days $([-45,-6]$ and $[+6,+45])$ around the ex-dividend day, scaled by the standard deviation of market stock returns over the same period. BETA2 is defined as the firm-specific market model beta estimated over the 80 trading days $([-45,-6]$ and $[+6,+45])$ around the ex-dividend day. 1/PRICE_ANN is defined as the inverse of the closing stock price on the dividend announcement day. 1/PRICE_CUM is defined as the inverse of cum-dividend day closing stock price.

Panel A. Summary Statistics for Key Variables

\begin{tabular}{|c|c|c|c|c|c|c|}
\hline \multirow[b]{2}{*}{ Variables } & \multirow[b]{2}{*}{$\begin{array}{l}\text { No. of } \\
\text { Obs. }\end{array}$} & \multirow[b]{2}{*}{ Mean } & \multirow[b]{2}{*}{ Std. Dev. } & \multicolumn{3}{|c|}{ Percentiles } \\
\hline & & & & 25th & 50th & 75th \\
\hline YIELD & 3,832 & 0.009 & 0.010 & 0.000 & 0.006 & 0.014 \\
\hline EVENT & 3,832 & 0.509 & 0.500 & 0.000 & 1.000 & 1.000 \\
\hline $\mathrm{HP}$ & 3,832 & -0.017 & 0.012 & -0.022 & -0.014 & -0.008 \\
\hline $\ln (\mathrm{MCAP})$ & 3,832 & 22.035 & 0.913 & 21.370 & 21.862 & 22.537 \\
\hline LEV & 3,832 & 0.464 & 0.231 & 0.284 & 0.472 & 0.635 \\
\hline $\mathrm{MB}$ & 3,832 & 2.852 & 2.673 & 1.526 & 2.201 & 3.243 \\
\hline ROE & 3,832 & 0.039 & 0.055 & 0.013 & 0.036 & 0.065 \\
\hline FCF & 3,832 & 0.055 & 0.137 & 0.013 & 0.069 & 0.129 \\
\hline $\mathrm{CASH}$ & 3,832 & 0.202 & 0.152 & 0.093 & 0.158 & 0.270 \\
\hline VOLATILITY & 3,832 & 0.112 & 0.034 & 0.089 & 0.108 & 0.130 \\
\hline RETURN & 3,832 & -0.138 & 0.289 & -0.355 & -0.181 & 0.018 \\
\hline SOE & 3,832 & 0.488 & 0.500 & 0.000 & 0.000 & 1.000 \\
\hline TOP1 & 3,832 & 0.361 & 0.158 & 0.234 & 0.341 & 0.475 \\
\hline TURNOVER & 2,208 & 0.018 & 0.018 & 0.006 & 0.012 & 0.023 \\
\hline ABTURNOVER & 2,208 & 0.000 & 0.021 & -0.003 & 0.001 & 0.007 \\
\hline RET_EX & 2,208 & -0.001 & 0.020 & -0.012 & -0.001 & 0.009 \\
\hline YIELD_ANN & 2,208 & 0.017 & 0.019 & 0.006 & 0.012 & 0.019 \\
\hline YIELD_CUM & 2,208 & 0.017 & 0.021 & 0.006 & 0.012 & 0.020 \\
\hline RISK 1 & 2,208 & 1.854 & 0.548 & 1.486 & 1.780 & 2.133 \\
\hline BETA1 & 2,208 & 1.164 & 0.304 & 0.966 & 1.152 & 1.349 \\
\hline RISK2 & 2,208 & 1.963 & 0.503 & 1.621 & 1.928 & 2.271 \\
\hline BETA2 & 2,208 & 1.069 & 0.293 & 0.862 & 1.068 & 1.262 \\
\hline 1/PRICE_ANN & 2,208 & 0.137 & 0.147 & 0.070 & 0.105 & 0.154 \\
\hline \multirow[t]{2}{*}{ 1/PRICE_CUM } & 2,208 & 0.141 & 0.158 & 0.070 & 0.107 & 0.158 \\
\hline & & & & & (continue & t page) \\
\hline
\end{tabular}


TABLE 1 (continued)

Summary Statistics

Panel B. Industry Distribution of Sample Firms

\begin{tabular}{lrrr}
\multicolumn{1}{c}{ Industry } & $\%$ & No. of Obs. & YIELD \\
\cline { 2 - 4 } Agriculture & $1.98 \%$ & 76 & 0.006 \\
Mining & $2.61 \%$ & 100 & 0.012 \\
Food & $4.04 \%$ & 155 & 0.008 \\
Apparel & $3.34 \%$ & 128 & 0.009 \\
Furniture & $0.42 \%$ & 16 & 0.010 \\
Printing & $1.75 \%$ & 67 & 0.009 \\
Gas and chemistry & $10.83 \%$ & 415 & 0.008 \\
Electronic & $5.98 \%$ & 229 & 0.009 \\
Metal & $8.27 \%$ & 317 & 0.007 \\
Machinery & $17.82 \%$ & 683 & 0.009 \\
Pharmaceutical products & $6.45 \%$ & 247 & 0.009 \\
Other manufacturing & $1.02 \%$ & 39 & 0.009 \\
Energy supply & $3.60 \%$ & 138 & 0.011 \\
Construction & $2.01 \%$ & 77 & 0.008 \\
Transportation & $3.58 \%$ & 137 & 0.016 \\
Information technology & $7.36 \%$ & 282 & 0.008 \\
Retail and wholesale & $5.77 \%$ & 221 & 0.010 \\
Real estate & $6.42 \%$ & 246 & 0.008 \\
Other service supply & $3.08 \%$ & 118 & 0.007 \\
Entertainment & $1.25 \%$ & 48 & 0.008 \\
Other & $2.43 \%$ & 93 & 0.007 \\
\hline
\end{tabular}

\section{FIGURE 1}

Corporate Dividend Policies around the 2012 Dividend Tax Reform: More Trading versus Fewer Trading Activities

Figure 1 shows the trends of average dividend yield (YIELD) for two groups of firms: firms whose investors have longer holding periods (High HP) and firms whose investors have shorter holding periods (Low HP). YIELD is constructed as annual cash dividends scaled by market capitalization at the previous fiscal year-end. HP is a proxy for investors' average holding periods, measured as the average daily share turnover in the whole year before the dividend announcement date, multiplied by -1 . For each year, we divide firms into two groups based on the value of HP. For each group, we construct the mean value of YIELD. We then plot the trend of these mean values.

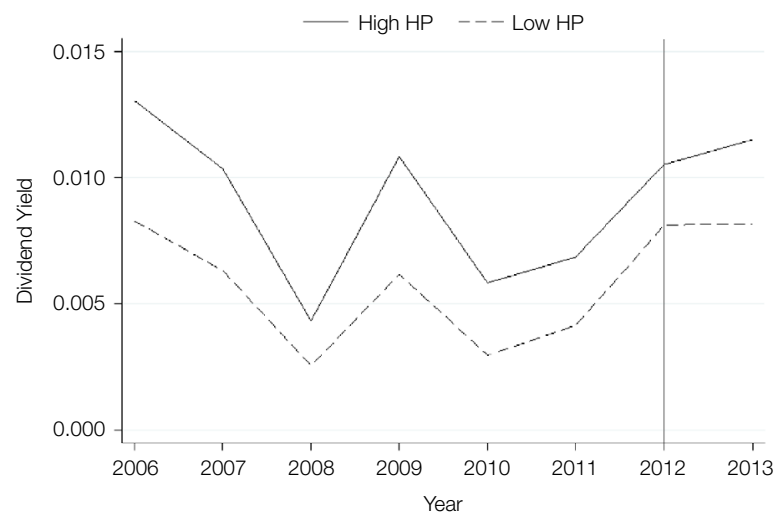

average share turnover in the year before its dividend announcement date. We then estimate the following model:

(5) $\mathrm{YIELD}_{i, t}=\alpha_{0}+\alpha_{1} \mathrm{EVENT}_{t}+\alpha_{2} \mathrm{HP}_{i, t}+\alpha_{3} \mathrm{EVENT}_{t} \times \mathrm{HP}_{i, t}+\eta X_{i, t-1}+\varepsilon_{i, t}$,

where YIELD $_{i, t}$, dividend yield, is calculated as annual cash dividends scaled by market capitalization at the previous fiscal year-end. EVENT $_{t}$ is an 
indicator that equals 1 for 2013 (postreform) and 0 for 2012 (prereform). ${ }^{14} \mathrm{HP}_{i, t}$, the proxy for the length of shareholding period, is constructed as the average daily share turnover during the year before the dividend announcement date, multiplied by $-1 .{ }^{15,16} \mathrm{~A}$ higher value of HP indicates lower turnover and a longer holding period. The coefficient on the interaction between EVENT and HP thus captures the relative change in dividend payout for firms whose individual investors have long holding periods compared to those of firms whose individual investors have short holding periods. If firms adapt their payout policies to investors' tax preferences, we expect $\alpha_{3}$ to be positive.

$X_{i, t-1}$ is a vector of control variables. We follow the prior literature in selecting determinants that have been shown to affect a firm's payout policy (Brown et al. (2007), Blouin et al. (2011)). They include ln(MCAP), the natural logarithm of a firm's market capitalization at the previous fiscal year-end; LEV, total liabilities divided by total assets at the previous fiscal year-end; MB, the market value of equity divided by the book value of equity at the previous fiscal yearend; ROE, net income during the previous fiscal year divided by the book value of equity at the previous fiscal year-end; FCF, free cash flow during the previous fiscal year divided by total assets at the previous fiscal year-end, where free cash flow equals operating income before interest expense and noncash payment (e.g., depreciation, amortization) minus capital expenditures; CASH, cash divided by total assets at the previous fiscal year-end; VOLATILITY, the standard deviation of monthly returns during the previous fiscal year; and RETURN, the stock return during the previous fiscal year. To incorporate the unique institution we examine, we further construct two measures of corporate ownership structure. In particular, we include an indicator for state-owned enterprises (SOEs). SOE is coded 1 if the controlling shareholder of a firm is a government entity, and 0 otherwise. Furthermore, we control the top shareholder's ownership. TOP1 is defined as the percentage of shares held by the largest shareholder at the previous fiscal yearend. Finally, we control for industry fixed effects and cluster standard errors at the firm level.

Empirically, we first estimate a parsimonious model including EVENT, HP, and EVENT $\times \mathrm{HP}$ as independent variables. Such a specification serves as a benchmark model resembling a univariate difference-in-differences estimation. Results in Table 2 suggest that firms with long-horizon individual investors increase dividend payout, compared to firms with short-horizon individual investors. Specifically, in column 1, the coefficient on EVENT $\times$ HP is positive and significant $(0.038, t=2.00)$. We then estimate the full model described in equation (5) that incorporates additional variables along with industry fixed effects. In column 2, the coefficient on EVENT $\times$ HP is again positive and significant $(0.045$, $t=2.48$ ), demonstrating that, compared to low-HP firms, high-HP firms increase

\footnotetext{
${ }^{14}$ The dividend tax reform was released Nov. 16, 2012 and became effective Jan. 1, 2013, so there was a gap between these two dates. However, this should not affect our analyses, as no firm announced an annual dividend payout during this short period.

${ }^{15}$ We require each firm to have at least 120 trading days during the year before its dividend announcement day in 2013.

${ }^{16}$ For a firm not issuing cash dividends, the dividend announcement date is the annual report release date.
} 
TABLE 2

Effect of Dividend Tax Reform on Firms' Dividend Payout

Table 2 presents results of the effect of dividend tax reform on firms' dividend payouts. The sample comprises 3,832 firmyear observations for 2012 and 2013. The dependent variable, YIELD, is constructed as annual cash dividends scaled by market capitalization at the previous fiscal year-end. HP is a proxy for investors' average holding period length, measured as the average daily share turnover in the whole year before the dividend announcement date, multiplied by -1. EVENT is an indicator that equals 1 for observations in 2013, and 0 for observations in 2012. All other variables are as defined in Table 1. The $t$-statistics computed with robust standard errors clustered at the firm level are reported in parentheses. ${ }^{*},{ }^{* *}$, and ${ }^{* * *}$ indicate significance at the $10 \%, 5 \%$, and $1 \%$ levels, respectively.

\begin{tabular}{|c|c|c|}
\hline \multirow[b]{2}{*}{ Variables } & \multicolumn{2}{|c|}{ YIELD } \\
\hline & 1 & 2 \\
\hline EVENT & $\begin{array}{l}0.001^{\star \star} \\
(2.57)\end{array}$ & $\begin{array}{l}0.002^{\star \star \star} \\
(5.22)\end{array}$ \\
\hline $\mathrm{HP}$ & $\begin{array}{l}0.109^{* \star \star} \\
(6.29)\end{array}$ & $\begin{array}{c}0.013 \\
(0.77)\end{array}$ \\
\hline EVENT $\times$ HP & $\begin{array}{l}0.038^{* \star} \\
(2.00)\end{array}$ & $\begin{array}{l}0.045^{\star \star} \\
(2.48)\end{array}$ \\
\hline $\ln (\mathrm{MCAP})$ & & $\begin{array}{l}0.002^{\star \star \star} \\
(8.45)\end{array}$ \\
\hline LEV & & $\begin{array}{l}-0.000 \\
(-0.39)\end{array}$ \\
\hline MB & & $\begin{array}{l}-0.001^{* \star *} \\
(-9.42)\end{array}$ \\
\hline ROE & & $\begin{array}{l}0.053^{\star \star \star} \\
(12.63)\end{array}$ \\
\hline FCF & & $\begin{array}{l}0.004^{\star \star \star} \\
(3.91)\end{array}$ \\
\hline CASH & & $\begin{array}{l}0.008^{\star \star \star} \\
(5.50)\end{array}$ \\
\hline VOLATILITY & & $\begin{array}{l}-0.024^{* \star *} \\
(-4.65)\end{array}$ \\
\hline RETURN & & $\begin{array}{l}-0.001^{\star} \\
(-1.95)\end{array}$ \\
\hline SOE & & $\begin{array}{l}-0.001^{\star \star x} \\
(-3.02)\end{array}$ \\
\hline TOP1 & & $\begin{array}{l}0.003^{\star \star} \\
(2.23)\end{array}$ \\
\hline Constant & $\begin{array}{l}0.010^{* * *} \\
(24.60)\end{array}$ & $\begin{array}{l}-0.039^{* \star *} \\
(-7.06)\end{array}$ \\
\hline Industry effects & No & Yes \\
\hline $\begin{array}{l}\text { No. of obs. } \\
\text { Adj. } R^{2}\end{array}$ & $\begin{array}{l}3,832 \\
0.025\end{array}$ & $\begin{array}{l}3,832 \\
0.282\end{array}$ \\
\hline
\end{tabular}

their dividend yield after the reform. The effect of the reform is also economically significant. For two firms at the first and third holding period quartiles, respectively, the difference between the changes in their dividend yields around the reform is $10.5 \%(((-0.008-(-0.022)) \times 0.045) / 0.006)$ of the median dividend yield of the sample. Collectively, the evidence here suggests that individual investors' dividend tax rates affect firms' dividend policies in a manner consistent with investors' tax preferences.

\section{Agency Cost}

Next, we examine whether the incentive deviation between controlling shareholders and minority shareholders affects the sensitivity of corporate payout to individual investors' dividend taxes. To gauge the extent of such an agency conflict, we employ a measure of the divergence between controlling shareholders' voting rights and cash-flow rights. As the ratio of voting rights to cash-flow 
rights increases, controlling shareholders bear disproportionately less economic consequence but derive a greater benefit from their expropriation activities. Prior studies suggest that a higher divergence leads to increased entrenchment and tunneling and lower firm value (Claessens et al. (2002), Masulis et al. (2009)).

We split the full sample into two subsamples based on the divergence between controlling shareholders' voting rights and cash-flow rights. We then estimate equation (5) in both subsamples to determine whether there is any difference in the sensitivity of corporate payout to individual investors' dividend tax rates. Results in columns 1 and 2 of Table 3 reveal that the change in dividend payout is concentrated in firms where the agency conflict between controlling shareholders and minority shareholders is less severe. In particular, the coefficient on EVENT $\times$ HP is insignificant in the subsample of firms with a divergence between controlling shareholders' voting rights and cash-flow rights $(0.031, t=1.01)$. It is positive and significant in the subsample of firms without such a divergence $(0.050, t=2.17)$. However, a Chow test shows that the difference between the two estimates is statistically insignificant $(F=0.25, p=0.620) .{ }^{17}$

In addition to the divergence between controlling shareholders' voting rights and cash-flow rights, we construct two measures that capture controlling shareholders' expropriation activities ex post. To be more specific, we measure a firm's related-party transactions and intercorporate loans that are associated with its controlling shareholder, because they capture the extent to which the controlling shareholder is misusing corporate resources (Jiang et al. (2010), Liao et al. (2014)). Our measure of related-party transaction, RPT, is defined as the ratio of a firm's related-party transactions associated with its controlling shareholder to total assets at the previous fiscal yearend (Liao et al. (2014)). Our measure of intercorporate loans, ORECTA, is defined as other receivables deflated by total assets at the previous fiscal year-end (Jiang et al. (2010)). We expect the effect of the dividend tax reform on corporate payout to be less pronounced in firms where these two types of activities are more prevalent.

We present results in columns 3-6 of Table 3. The coefficient on EVENT $\times \mathrm{HP}$ is negative and insignificant $(-0.009, t=-0.31)$ in the subsample of firms with more related-party transactions. However, it is positive and significant $(0.089, t=3.81)$ in the subsample of firms with fewer related-party transactions. In addition, we find that the coefficient on EVENT $\times$ HP is insignificant in firms with more intercorporate loans $(0.014, t=0.56)$. In contrast, it is positive and significant $(0.080, t=2.99)$ in firms with fewer intercorporate loans. A Chow test reveals that the difference between the two coefficients is statistically significant when we use either related-party transactions $(F=6.25, p=0.013)$ or intercorporate loans $(F=3.00, p=0.083)$ to measure agency conflict.

\footnotetext{
${ }^{17}$ One possibility is that the difference in the divergence of controlling shareholders' voting rights and cash-flow rights of the two subsamples is not sufficiently large. We perform a more extreme split. In the subgroup of firms whose controlling shareholders have a divergence in their voting rights and cash-flow rights, we retain only those with divergence exceeding the 90th percentile of the sample distribution. Comparing results of this subsample with those of the subsample with no divergence, a Chow test reveals that the difference in the two coefficient estimates is statistically significant $(F=$ 2.96, $p=0.086)$.
} 


\section{TABLE 3 \\ Conditioning Effects of the Agency Conflict between the Controlling Shareholder and Minority Shareholders}

Table 3 presents results of the effect of dividend tax reform on firms' dividend payouts, conditioning on the agency conflict between the controlling shareholder and minority shareholders. In columns 1 and 2, we split the sample into two subsamples based on whether there is a divergence between a firm's controlling shareholder's voting rights and cash-flow rights. In columns 3 and 4, we split the sample into two subsamples based on whether the level of relatedparty transactions associated with the controlling shareholder (RPT) is higher or lower (including being equal to) than the median. RPT is defined as the ratio of firms' related-party transactions associated with controlling shareholders to total assets at the previous fiscal year-end (Liao, Liu, and Wang (2014)). In columns 5 and 6, we split the sample into two subsamples based on whether the level of intercorporate loans (ORECTA) to the controlling shareholder is higher or lower (including being equal to) than the median. ORECTA is defined as other receivables deflated by total assets at the previous fiscal year-end (Jiang et al. (2010)). We then estimate the effect of dividend tax reform on firms' dividend policies separately in each of the six subsamples. The dependent variable, YIELD, is constructed as annual cash dividends scaled by market capitalization at the previous fiscal year-end. HP is a proxy for investors' average holding period, measured as the average daily share turnover in the whole year before the dividend announcement date, multiplied by -1. EVENT is an indicator that equals 1 for observations in 2013, and 0 for observations in 2012. All other variables are as defined in Table 1. Sample size is reduced due to missing values for voting rights and cash-flow rights. The $t$-statistics computed with robust standard errors clustered at the firm level are reported in parentheses. ${ }^{*}$, ${ }^{* *}$, and ${ }^{* * *}$ indicate significance at the $10 \%, 5 \%$, and $1 \%$ levels, respectively.

\begin{tabular}{|c|c|c|c|c|c|c|}
\hline \multirow[b]{2}{*}{ Variables } & \multicolumn{2}{|c|}{$\begin{array}{c}\text { Divergence between } \\
\text { Controlling } \\
\text { Shareholders' } \\
\text { Voting Rights } \\
\text { and Cash-Flow } \\
\text { Rights } \\
\end{array}$} & \multicolumn{2}{|c|}{ RPT } & \multicolumn{2}{|c|}{ ORECTA } \\
\hline & With & Without & High & Low & More & Less \\
\hline EVENT & $\begin{array}{l}0.002^{\star \star} \\
(2.34)\end{array}$ & $\begin{array}{l}0.003^{\star \star \star} \\
(4.67)\end{array}$ & $\begin{array}{c}0.001 \\
(1.44)\end{array}$ & $\begin{array}{l}0.004^{\star \star \star} \\
(5.40)\end{array}$ & $\begin{array}{l}0.002^{* * *} \\
(3.08)\end{array}$ & $\begin{array}{l}0.003^{\star \star \star} \\
(4.16)\end{array}$ \\
\hline HP & $\begin{array}{l}0.045^{\star} \\
(1.67)\end{array}$ & $\begin{array}{l}-0.013 \\
(-0.55)\end{array}$ & $\begin{array}{c}0.034 \\
(1.31)\end{array}$ & $\begin{array}{c}0.004 \\
(0.18)\end{array}$ & $\begin{array}{l}-0.001 \\
(-0.05)\end{array}$ & $\begin{array}{c}0.025 \\
(0.91)\end{array}$ \\
\hline EVENT $\times$ HP & $\begin{array}{r}0.031 \\
(1.01)\end{array}$ & $\begin{array}{l}0.050^{* *} \\
(2.17)\end{array}$ & $\begin{array}{l}-0.009 \\
(-0.31)\end{array}$ & $\begin{array}{l}0.089^{\text {*ᄎ }} \\
(3.81)\end{array}$ & $\begin{array}{c}0.014 \\
(0.56)\end{array}$ & $\begin{array}{l}0.080^{\star \star \star} \\
(2.99)\end{array}$ \\
\hline $\ln (\mathrm{MCAP})$ & $\begin{array}{l}0.002^{\star \star \star} \\
(5.66)\end{array}$ & $\begin{array}{l}0.002^{\star \star \star} \\
(6.54)\end{array}$ & $\begin{array}{l}0.002^{\star \star \star} \\
(7.07)\end{array}$ & $\begin{array}{l}0.002^{\star \star \star} \\
(4.90)\end{array}$ & $\begin{array}{l}0.002^{* * *} \\
(7.10)\end{array}$ & $\begin{array}{l}0.002^{\star \star \star} \\
(5.30)\end{array}$ \\
\hline LEV & $\begin{array}{r}0.000 \\
(0.17)\end{array}$ & $\begin{array}{l}-0.001 \\
(-0.82)\end{array}$ & $\begin{array}{l}-0.001 \\
(-0.84)\end{array}$ & $\begin{array}{c}0.002 \\
(1.53)\end{array}$ & $\begin{array}{l}-0.000 \\
(-0.27)\end{array}$ & $\begin{array}{l}-0.000 \\
(-0.19)\end{array}$ \\
\hline $\mathrm{MB}$ & $\begin{array}{l}-0.001^{\star \star \star} \\
(-7.06)\end{array}$ & $\begin{array}{l}-0.001^{\text {** }} \\
(-5.96)\end{array}$ & $\begin{array}{l}-0.001^{\star \star \star} \\
(-7.08)\end{array}$ & $\begin{array}{l}-0.001^{\star \star \star} \\
(-6.95)\end{array}$ & $\begin{array}{l}-0.001^{\star \star \star} \\
(-7.79)\end{array}$ & $\begin{array}{l}-0.001^{\text {} \star \star \star ~} \\
(-5.83)\end{array}$ \\
\hline ROE & $\begin{array}{l}0.050^{\star \star \star} \\
(8.70)\end{array}$ & $\begin{array}{l}0.056^{\star \star \star} \\
(8.67)\end{array}$ & $\begin{array}{l}0.046^{\star \star \star} \\
(8.77)\end{array}$ & $\begin{array}{l}0.060^{\star \star \star} \\
(9.20)\end{array}$ & $\begin{array}{l}0.040^{\star \star *} \\
(8.14)\end{array}$ & $\begin{array}{l}0.069^{\star \star \star} \\
(10.47)\end{array}$ \\
\hline FCF & $\begin{array}{l}0.004^{\star \star \star} \\
(3.22)\end{array}$ & $\begin{array}{l}0.003^{*} \\
(1.84)\end{array}$ & $\begin{array}{l}0.004^{\star \star \star} \\
(3.28)\end{array}$ & $\begin{array}{l}0.003^{*} \\
(1.71)\end{array}$ & $\begin{array}{l}0.003^{\star *} \\
(2.38)\end{array}$ & $\begin{array}{l}0.004^{\star \star} \\
(2.57)\end{array}$ \\
\hline CASH & $\begin{array}{l}0.009^{\star \star \star} \\
(4.29)\end{array}$ & $\begin{array}{l}0.006^{\star \star \star} \\
(3.18)\end{array}$ & $\begin{array}{l}0.008^{\star \star \star} \\
(3.46)\end{array}$ & $\begin{array}{l}0.008^{\star \star \star} \\
(4.26)\end{array}$ & $\begin{array}{l}0.006^{\star * *} \\
(3.10)\end{array}$ & $\begin{array}{l}0.008^{\star \star \star} \\
(4.11)\end{array}$ \\
\hline VOLATILITY & $\begin{array}{l}-0.011 \\
(-1.50)\end{array}$ & $\begin{array}{l}-0.036^{\star \star \star} \\
(-4.87)\end{array}$ & $\begin{array}{l}-0.017^{\star \star} \\
(-2.36)\end{array}$ & $\begin{array}{l}-0.028^{\star \star \star} \\
(-3.73)\end{array}$ & $\begin{array}{l}-0.022^{\star \star \star} \\
(-3.14)\end{array}$ & $\begin{array}{l}-0.026^{\star \star \star} \\
(-3.37)\end{array}$ \\
\hline RETURN & $\begin{array}{l}-0.001 \\
(-1.20)\end{array}$ & $\begin{array}{l}-0.002 \\
(-1.63)\end{array}$ & $\begin{array}{l}0.000 \\
(0.04)\end{array}$ & $\begin{array}{l}-0.003^{\star \star \star} \\
(-2.65)\end{array}$ & $\begin{array}{l}-0.002^{\star} \\
(-1.80)\end{array}$ & $\begin{array}{l}-0.001 \\
(-0.89)\end{array}$ \\
\hline SOE & $\begin{array}{l}-0.001 \\
(-1.21)\end{array}$ & $\begin{array}{l}-0.001^{\star *} \\
(-2.52)\end{array}$ & $\begin{array}{l}-0.001^{\star \star} \\
(-2.38)\end{array}$ & $\begin{array}{l}-0.001 \\
(-1.41)\end{array}$ & $\begin{array}{l}-0.001 \\
(-1.40)\end{array}$ & $\begin{array}{l}-0.001^{\star \star \star} \\
(-2.64)\end{array}$ \\
\hline TOP1 & $\begin{array}{l}0.004^{\star \star} \\
(2.34)\end{array}$ & $\begin{array}{l}0.001 \\
(0.71)\end{array}$ & $\begin{array}{l}0.004^{\star \star} \\
(2.26)\end{array}$ & $\begin{array}{l}0.003^{*} \\
(1.93)\end{array}$ & $\begin{array}{l}0.004^{* *} \\
(2.45)\end{array}$ & $\begin{array}{r}0.001 \\
(0.84)\end{array}$ \\
\hline Constant & $\begin{array}{l}-0.042^{\star \star \star} \\
(-5.01)\end{array}$ & $\begin{array}{l}-0.041^{* \star *} \\
(-5.23)\end{array}$ & $\begin{array}{l}-0.046^{\star \star \star} \\
(-6.01)\end{array}$ & $\begin{array}{l}-0.032^{\star \star \star} \\
(-4.02)\end{array}$ & $\begin{array}{l}-0.047^{\star \star *} \\
(-6.30)\end{array}$ & $\begin{array}{l}-0.032^{\star \star \star} \\
(-4.03)\end{array}$ \\
\hline $\begin{array}{l}\text { Chow tests of coefficients on } \\
\text { EVENT } \times \mathrm{HP}\end{array}$ & $\begin{array}{l}F= \\
p=\end{array}$ & & & .25 & $\begin{array}{l}F= \\
p=\end{array}$ & 00 \\
\hline Industry effects & Yes & Yes & Yes & Yes & Yes & Yes \\
\hline $\begin{array}{l}\text { No. of obs. } \\
\text { Adj. } R^{2}\end{array}$ & $\begin{array}{l}1,755 \\
0.269\end{array}$ & $\begin{array}{l}1,918 \\
0.302\end{array}$ & $\begin{array}{l}1,916 \\
0.271\end{array}$ & $\begin{array}{l}1,916 \\
0.300\end{array}$ & $\begin{array}{l}1,916 \\
0.274\end{array}$ & $\begin{array}{l}1,916 \\
0.290\end{array}$ \\
\hline
\end{tabular}


The above results suggest that in a setting where concentrated ownership is the norm, the sensitivity of corporate payout to individual investors' dividend taxes can be altered by the agency conflict between controlling shareholders and minority shareholders.

\section{Investors' Trading Activities around the Dividend Tax Reform}

To determine whether investors adjust their trading behaviors in response to an exogenous shock to the dividend tax rate, we compare the change in share turnover of high-dividend-yield firms with that of low-dividend-yield firms. We estimate the following equation:

$$
\begin{aligned}
& \text { TURNOVER }_{i, t} \text { or ABTURNOVER }{ }_{i, t}=\beta_{0}+\beta_{1} \text { YIELD_ANN }_{i, t}
\end{aligned}
$$

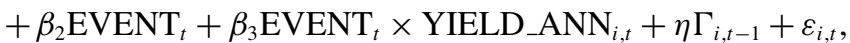

where TURNOVER is the average daily share turnover during the month before the cum-dividend day. ${ }^{18}$ Alternatively, we construct the variable ABTURNOVER to capture abnormal turnover as the following:

$$
\text { ABTURNOVER }_{i, t}=\text { TURNOVER }_{i, t}-\text { NTURNOVER }_{i, t},
$$

where NTURNOVER is the average daily share turnover during the 60-day period leading to the date of the dividend tax reform (Nov. 16, 2012). For observations in 2012, we assign to them a pseudo reform date of Nov. 16, 2011 when measuring NTURNOVER. YIELD_ANN equals announced cash dividends deflated by market capitalization on the dividend announcement day. EVENT equals 1 for an observation of dividend payment in 2013, and 0 for an observation in 2012. Hypothesis 3 suggests that investors are more likely to reduce their trading activities before the cum-dividend day for firms paying more dividends. The coefficient on the interaction term EVENT $\times$ YIELD_ANN thus captures the effect of the dividend reform on investors' trading activities. If investors reduce their trading activities during the month before the cum-dividend day to enjoy a lower dividend tax rate, we expect $\beta_{3}$ to be negative.

$\Gamma_{i, t-1}$ is a vector of control variables. We include the following variables that affect investors' trading activities identified in the prior literature (Michaely and Vila ((1995), (1996)), Dhaliwal and Li (2006)). RISK1 is the standard deviation of firm-specific stock returns during the 60-day period preceding the date of the dividend tax reform (Nov. 16, 2012), scaled by the standard deviation of market returns over the same period. BETA1 is the firm-specific market model beta estimated over the 60-day period preceding the dividend tax reform date. For observations in 2012, we assign to them a pseudo reform date of Nov. 16, 2011 when measuring RISK1 and BETA1. 1/PRICE_ANN is the inverse of the closing stock price on the dividend announcement day. $\ln (\mathrm{MCAP}), \mathrm{LEV}, \mathrm{MB}, \mathrm{ROE}$, and VOLATILITY are as previously defined. We again include industry fixed effects and cluster standard errors at the firm level.

Results in Table 4 reveal that investors in high-dividend-yield firms decrease their trading activities after the reform compared to investors in low-dividend-

\footnotetext{
day.

${ }^{18}$ We require each firm to have at least 10 trading days during the month before its cum-dividend
} 
TABLE 4

Effect of Dividend Tax Reform on Investors' Trading Activities before the Cum-Dividend Day

Table 4 presents results of the effect of dividend tax reform on investors' trading activities during the month before the cum-dividend day. We use two alternative measures of investors' trading activities. TURNOVER is measured as the average daily turnover in the 1 month before the cum-dividend day. ABTURNOVER is measured as the difference between TURNOVER and NTURNOVER, where NTURNOVER is measured as the average daily turnover in the 60 days before the date of the dividend tax reform (Nov. 16, 2012). For observations in 2012, we assign a pseudo reform date of Nov. 16, 2011 when measuring NTURNOVER. YIELD_ANN is constructed as annual cash dividends scaled by market capitalization on the dividend announcement day. EVENT is an indicator that equals 1 for observations in 2013, and 0 for observations in 2012. All other variables are as defined in Table 1. The $t$-statistics computed with robust standard errors clustered at the firm level are reported in parentheses. ${ }^{*}$, ${ }^{* *}$, and ${ }^{* * *}$ indicate significance at the $10 \%, 5 \%$, and $1 \%$ levels, respectively.

\begin{tabular}{|c|c|c|c|c|}
\hline Variables & TURNOVER & ABTURNOVER & TURNOVER & ABTURNOVER \\
\hline EVENT & $\begin{array}{l}0.006^{\star \star \star} \\
(6.75)\end{array}$ & $\begin{array}{l}0.008^{\star \star \star} \\
(6.78)\end{array}$ & $\begin{array}{l}0.002^{\star \star} \\
(2.56)\end{array}$ & $\begin{array}{l}0.014^{\star \star \star} \\
(12.62)\end{array}$ \\
\hline YIELD_ANN & $\begin{array}{l}-0.170^{\star \star *} \\
(-12.20)\end{array}$ & $\begin{array}{l}0.031^{\star \star} \\
(2.09)\end{array}$ & $\begin{array}{l}-0.056^{\star \star \star} \\
(-2.94)\end{array}$ & $\begin{array}{r}0.010 \\
(0.50)\end{array}$ \\
\hline EVENT $\times$ YIELD_ANN & $\begin{array}{l}-0.073^{\text {** }} \\
(-3.03)\end{array}$ & $\begin{array}{l}-0.077^{\star \star \star} \\
(-3.30)\end{array}$ & $\begin{array}{l}-0.048^{* *} \\
(-2.10)\end{array}$ & $\begin{array}{l}-0.150^{\star \star \star} \\
(-5.82)\end{array}$ \\
\hline RISK1 & & & $\begin{array}{l}0.009^{* * *} \\
(6.68)\end{array}$ & $\begin{array}{l}-0.021^{\star \star \star} \\
(-11.69)\end{array}$ \\
\hline BETA1 & & & $\begin{array}{l}-0.004^{* *} \\
(-2.50)\end{array}$ & $\begin{array}{l}0.009^{\star \star \star} \\
(4.03)\end{array}$ \\
\hline 1/PRICE_ANN & & & 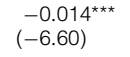 & $\begin{array}{l}-0.015^{\star \star \star} \\
(-6.67)\end{array}$ \\
\hline $\ln (\mathrm{MCAP})$ & & & $\begin{array}{l}-0.003^{* * *} \\
(-7.53)\end{array}$ & $\begin{array}{l}-0.002^{\star \star \star} \\
(-3.62)\end{array}$ \\
\hline LEV & & & $\begin{array}{l}-0.013^{\star * \star} \\
(-7.15)\end{array}$ & $\begin{array}{l}0.006^{\star \star \star} \\
(2.72)\end{array}$ \\
\hline MB & & & $\begin{array}{r}0.000 \\
(0.33)\end{array}$ & $\begin{array}{l}0.001^{\star \star \star} \\
(2.69)\end{array}$ \\
\hline ROE & & & $\begin{array}{r}0.004 \\
(0.57)\end{array}$ & $\begin{array}{l}-0.002 \\
(-0.30)\end{array}$ \\
\hline VOLATILITY & & & $\begin{array}{l}0.106^{\star * \star} \\
(6.64)\end{array}$ & $\begin{array}{l}-0.032 \\
(-1.31)\end{array}$ \\
\hline Constant & $\begin{array}{l}0.018^{\star * \star} \\
(28.28)\end{array}$ & $\begin{array}{l}-0.004^{\star \star \star} \\
(-4.57)\end{array}$ & $\begin{array}{l}0.062^{* * *} \\
(6.99)\end{array}$ & $\begin{array}{l}0.054^{\star \star *} \\
(5.22)\end{array}$ \\
\hline Industry effects & No & No & Yes & Yes \\
\hline $\begin{array}{l}\text { No. of obs. } \\
\text { Adj. } R^{2}\end{array}$ & $\begin{array}{l}2,208 \\
0.066\end{array}$ & $\begin{array}{l}2,208 \\
0.024\end{array}$ & $\begin{array}{l}2,208 \\
0.330\end{array}$ & $\begin{array}{l}2,208 \\
0.255\end{array}$ \\
\hline
\end{tabular}

yield firms. Specifically, in columns 1 and 2, we estimate two parsimonious models including only EVENT, YIELD_ANN, and EVENT $\times$ YIELD_ANN as independent variables. The coefficients on EVENT $\times$ YIELD_ANN are negative and significant in both specifications $(-0.073, t=-3.03$ for TURNOVER; $-0.077, t=-3.30$ for ABTURNOVER). We then estimate a full model incorporating other control variables. The coefficients on EVENT $\times$ YIELD_ANN remain negative and significant using both share turnover measures $(-0.048$, $t=-2.10$ for TURNOVER; $-0.150, t=-5.82$ for ABTURNOVER). This result is consistent with the notion that investors adjust their trading activities to lower their dividend tax rates. ${ }^{19}$

\footnotetext{
${ }^{19}$ There also appears to be a positive association between dividend yield and abnormal share turnover $(0.031, t=2.09$ in column 2 of Table $4 ; 0.010, t=0.50$ in column 4$)$. Such a finding is consistent with the tax-clientele view that investors have different preferences toward dividends primarily due to their tax heterogeneity (Graham et al. (2003)). After firms announce high dividends, investors with lower dividend tax rates try to acquire shares to capture dividends, whereas investors with higher dividend tax rates try to sell shares to avoid dividends (Dhaliwal and Li (2006)), creating volume.
} 
In theory, investors may also have an incentive to reduce trading outside the 1-month period because holding shares longer than 1 year further reduces the dividend tax rate from $10 \%$ to $5 \%$. We select a 1 -month period before the cum-dividend day for three primary reasons. First, the 1-month cutoff generates a larger dividend tax rate difference (10\% to $20 \%$ ) compared to the 1-year cutoff ( $5 \%$ to $10 \%)$. Second, as the dividend announcement day generally precedes the cum-dividend day by approximately 70 days, the 1-month period ensures that trading activities most likely occur after investors observe the dividend announcement information. Third, trading too far away from the cum-dividend day can subject investors to risks associated with fluctuations in stock prices. Nevertheless, we examine investors' trading patterns during the second, third, and fourth months before a firm's cum-dividend day. If we move too far away from the cum-dividend day, we will be entering the prereform period. In untabulated analysis, we find weak evidence that investors reduce their trading activities for high-dividend-payout firms during these windows. The coefficient on EVENT $\times$ YIELD_ANN is negative and significant during all months when the dependent variable is abnormal turnover. However, the most pronounced effect occurs during the first month before the cum-dividend day (Table 4). When we use average daily turnover as the dependent variable, the coefficient on EVENT $\times$ YIELD_ANN is insignificant for the second, third, or fourth month before the cum-dividend day.

Our results support the view of dividend clienteles, which states that firms with high dividend payouts are owned by investors with low tax rates (e.g., institutional investors). However, different from prior studies examining the association between a firm's dividend payout and its institutional ownership, we show that investors themselves alter their dividend tax rates when they are able to do so. More specifically, investors in firms with higher dividend payouts respond to the dividend tax reform by lowering their share turnovers to enter into a lower dividend tax bracket.

\section{E. Muted Trading after the Cum-Dividend Day?}

Ultimately, the dividend tax rate is determined on the share-selling date. Investors who purchase shares shortly before the cum-dividend day can continue to hold shares and thus have lower share turnover after the cum-dividend day. To determine whether this is the case, we plot weekly abnormal share turnover from 16 weeks before to 16 weeks after the week of the cum-dividend day in 2013 (postreform). Weekly abnormal share turnover is defined as the average daily share turnover during the week minus the average daily share turnover during the 60-day period preceding the date of the dividend tax reform. We divide firms into two groups. The first group (LOWYIELD) includes firms with lower-thanmedian (or equal-to-median) annual dividend yields in 2013. The second group (HIGHYIELD) includes firms with higher-than-median annual dividend yields in 2013.

Figure 2 shows that investors reduce their trading before the cum-dividend day. The trend begins to revert approximately 2 (3) weeks before the cum-dividend day for high-yield (low-yield) firms, potentially due to the increase in clientelebased trading shortly before the cum-dividend day (Dhaliwal and Li (2006), Graham et al. (2003)). After the cum-dividend day, share turnover significantly 
FIGURE 2

Weekly Abnormal Share Turnover around the Cum-Dividend Day

Figure 2 plots weekly abnormal share turnover from 16 weeks before to 16 weeks after the week of the cum-dividend day in 2013 for two groups of firms. The first group (LOWYIELD) comprises firms that have lower-than-median (or equal-tomedian) annual dividend yields in 2013. The second group (HIGHYIELD) comprises firms that have higher-than-median annual dividend yields in 2013. For each firm, weekly abnormal share turnover is defined as the average daily share turnover during a week minus the average daily share turnover during the 60-day period leading to the date of the dividend tax reform. We then plot the mean weekly abnormal share turnover for each group.

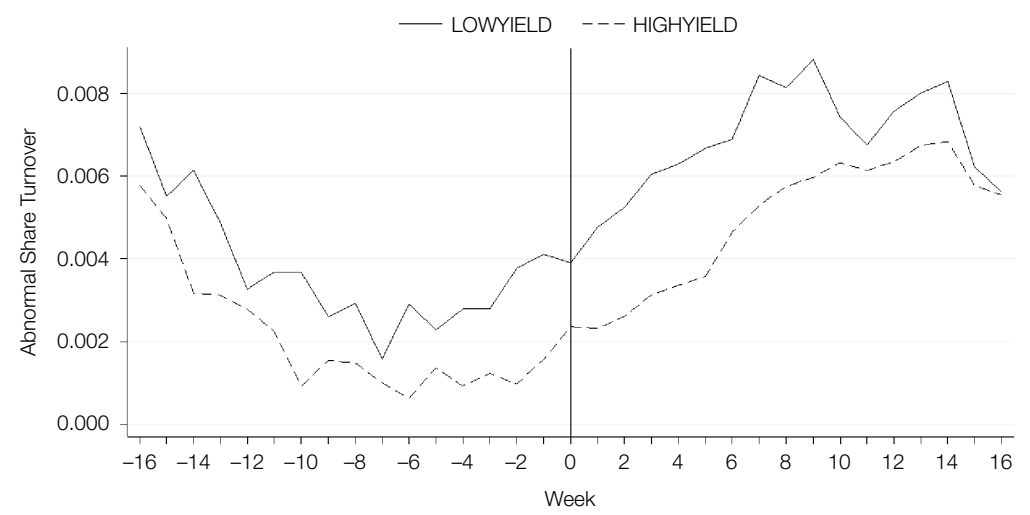

increases, consistent with the notion that at least some individual investors who withhold their trading incentives before the cum-dividend day trade shares subsequently.

The unconditional result in Figure 2 is inconsistent with the conjecture that individuals continue to hold their shares and thus have lower turnover after the cum-dividend day. However, such an incentive is more detectable if we condition our analysis on investors' trading activities before the cum-dividend day. Specifically, we divide high-yield firms into two groups based on their abnormal share turnover during the month before the cum-dividend day. The first group (HIGHYIELD_LOWTO) comprises firms with lower-than-median (or equal-tomedian) abnormal share turnover during the month before the cum-dividend day. The second group (HIGHYIELD_HIGHTO) comprises firms with higher-thanmedian abnormal share turnover during the month before the cum-dividend day. We then plot abnormal weekly share turnover for both groups in Figure 3. We observe that firms with high share turnover before the cum-dividend day experience a temporary decline in share turnover after the cum-dividend day. In contrast, firms with low share turnover before the cum-dividend day experience an increase in share turnover after the cum-dividend day.

In sum, we find support for muted trading after the cum-dividend day for firms with high turnover shortly before the cum-dividend day. However, the effect of the dividend tax reform on reducing investors' trading activities is more pronounced during the period before the cum-dividend day than during the period after.

\section{F. Stock Returns on the Ex-Dividend Day}

To determine whether investors successfully reduce their dividend taxes by trading less during the month before the cum-dividend day, we employ the 


\section{FIGURE 3}

Weekly Abnormal Share Turnover around the Cum-Dividend Day: Subsamples Formed by Abnormal Share Turnover during the Month before the Cum-Dividend Day

Figure 3 plots weekly abnormal share turnover from 16 weeks before to 16 weeks after the week of the cum-dividend day in 2013 for two groups of firms. The first group (HIGHYIELD_LOWTO) comprises firms that have higher-than-median annual dividend yields in 2013 and lower-than-median (equal-to-median) abnormal share turnover during the month before the cum-dividend day. The second group (HIGHYIELD_HIGHTO) comprises firms that have higher-than-median annual dividend yields in 2013 and higher-than-median abnormal share turnover during the month before the cumdividend day. For each firm, weekly abnormal share turnover is defined as the average daily share turnover during a week minus the average daily share turnover during the 60-day period leading to the date of the dividend tax reform. We then plot the mean weekly abnormal share turnover for each group.

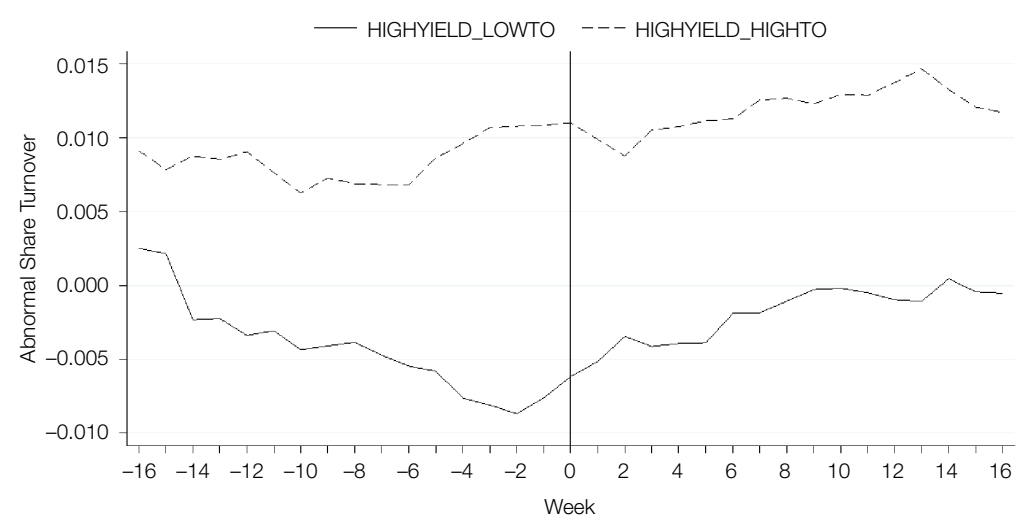

following regression:

$$
\begin{aligned}
\text { RET } & \text { EX }_{i, t}=\gamma_{0}+\gamma_{1} \text { YIELD_CUM }_{i, t}+\gamma_{2} \text { EVENT }_{t} \\
& +\gamma_{3} \text { EVENT }_{t} \times \text { YIELD_CUM }_{i, t}+\gamma_{4} \text { TURNOVER }_{i, t} \\
& +\gamma_{5} \text { TURNOVER }_{i, t} \times \text { YIELD_CUM }_{i, t}+\gamma_{6} \text { EVENT }_{t} \times \text { TURNOVER }_{i, t} \\
& +\gamma_{7} \text { EVENT }_{t} \times \text { TURNOVER }_{i, t} \times \text { YIELD_CUM }_{i, t}+\eta \Psi_{i, t-1}+\varepsilon_{i, t},
\end{aligned}
$$

where RET_EX is the excess stock return on the ex-dividend day, defined as stock return minus expected return based on a market model estimated over an 80-day period including the two windows $[-45,-6]$ and $[+6,+45]$, where day 0 is the ex-dividend day. ${ }^{20}$ EVENT equals 1 for a dividend payment in 2013, and 0 for a dividend payment in 2012. YIELD_CUM equals annual cash dividends deflated by market capitalization on the cum-dividend day. TURNOVER equals the average daily share turnover during the month before the cum-dividend day. Our variable of interest is the interaction term EVENT $\times$ TURNOVER $\times$ YIELD_CUM. After the reform, investors of firms with high share turnover during the month before the cum-dividend day are more likely to face an increase in their dividend tax rates. As such, we expect the coefficient on EVENT $\times$ TURNOVER $\times$ YIELD_CUM to be positive.

$\Psi_{i, t-1}$ is a vector of control variables. Following the prior literature ( $\mathrm{Li}$ and Weber (2009)), we include RISK2, defined as the standard deviation of firmspecific stock returns over the 80 trading days $([-45,-6]$ and $[+6,+45])$ around

\footnotetext{
${ }^{20}$ The market return used in the market model is constructed as the value-weighted return of all stocks. Our inference remains when using the equal-weighted stock return.
} 
the ex-dividend day, scaled by the standard deviation of market stock returns over the same period; BETA2, defined as the firm-specific market model beta estimated over the 80 trading days $([-45,-6]$ and $[+6,+45])$ around the ex-dividend day; 1/PRICE_CUM, defined as the inverse of the cum-dividend day closing stock price; and $\ln (\mathrm{MCAP}), \mathrm{LEV}, \mathrm{MB}, \mathrm{ROE}$, and VOLATILITY, as previously defined. We also include industry fixed effects and cluster standard errors at the firm level.

We present results in Table 5. To ensure that the observed effect is not due to the reform's effect on control variables, we first estimate a parsimonious model followed by a full model incorporating additional control variables. Column 1 shows that the coefficient on EVENT $\times$ TURNOVER $\times$ YIELD_CUM is positive and significant $(13.674, t=2.75)$. This finding is further confirmed when we

\title{
TABLE 5
}

\section{Effect of Dividend Tax Reform on Ex-Dividend Day Stock Return}

\begin{abstract}
Table 5 presents results of the effect of dividend tax reform on ex-dividend day stock return. RET_EX is the excess stock return on the ex-dividend day, defined as stock return minus expected return constructed from the market model. The market model is estimated over the 80 days including the two windows $[-45,-6]$ and $[+6,+45]$, where day 0 is the exdividend day. YIELD_CUM is constructed as annual cash dividends scaled by market capitalization on the cum-dividend day. TURNOVER is measured as the average daily turnover in the 1 month before the cum-dividend day. EVENT is an indicator that equals 1 for observations in 2013, and 0 for observations in 2012. All other variables are as defined in Table 1 . The $t$-statistics computed with robust standard errors clustered at the firm level are reported in parentheses. * and ${ }^{* * *}$ indicate significance at the $10 \%$ and $1 \%$ levels, respectively.
\end{abstract}

\begin{tabular}{|c|c|c|}
\hline \multirow{2}{*}{ Variables } & \multicolumn{2}{|c|}{ RET_EX } \\
\hline & 1 & 2 \\
\hline EVENT & $\begin{array}{r}0.001 \\
(0.72)\end{array}$ & $\begin{array}{l}0.002 \\
(1.18)\end{array}$ \\
\hline YIELD_CUM & $\begin{array}{l}0.010 \\
(0.35)\end{array}$ & $\begin{array}{l}-0.006 \\
(-0.17)\end{array}$ \\
\hline TURNOVER & $\begin{array}{l}0.093 \\
(1.54)\end{array}$ & $\begin{array}{l}0.115^{\star} \\
(1.75)\end{array}$ \\
\hline EVENT × YIELD_CUM & $\begin{array}{l}-0.021 \\
(-0.59)\end{array}$ & $\begin{array}{l}-0.029 \\
(-0.78)\end{array}$ \\
\hline EVENT $\times$ TURNOVER & $\begin{array}{l}-0.097 \\
(-1.31)\end{array}$ & $\begin{array}{l}-0.124 \\
(-1.63)\end{array}$ \\
\hline TURNOVER $\times$ YIELD_CUM & $\begin{array}{l}-19.399^{\star * *} \\
(-4.69)\end{array}$ & $\begin{array}{l}-21.540^{\star \star *} \\
(-5.11)\end{array}$ \\
\hline EVENT $\times$ TURNOVER $\times$ YIELD_CUM & $\begin{array}{l}13.674^{\star \star \star} \\
(2.75)\end{array}$ & $\begin{array}{l}15.747^{\star \star \star} \\
(3.18)\end{array}$ \\
\hline RISK2 & & $\begin{array}{r}0.001 \\
(0.76)\end{array}$ \\
\hline BETA2 & & $\begin{array}{l}-0.001 \\
(-0.65)\end{array}$ \\
\hline 1/PRICE_CUM & & $\begin{array}{l}0.003 \\
(1.21)\end{array}$ \\
\hline $\ln (\mathrm{MCAP})$ & & $\begin{array}{l}0.000 \\
(0.08)\end{array}$ \\
\hline LEV & & $\begin{array}{l}-0.003 \\
(-1.20)\end{array}$ \\
\hline MB & & $\begin{array}{l}-0.001 \\
(-1.07)\end{array}$ \\
\hline ROE & & $\begin{array}{l}0.017^{*} \\
(1.89)\end{array}$ \\
\hline VOLATILITY & & $\begin{array}{l}-0.025 \\
(-1.64)\end{array}$ \\
\hline Constant & $\begin{array}{r}0.001 \\
(0.53)\end{array}$ & $\begin{array}{r}0.001 \\
(0.07)\end{array}$ \\
\hline Industry effects & No & Yes \\
\hline $\begin{array}{l}\text { No. of obs. } \\
\text { Adj. } R^{2}\end{array}$ & $\begin{array}{l}2,208 \\
0.019\end{array}$ & $\begin{array}{l}2,208 \\
0.023\end{array}$ \\
\hline
\end{tabular}


estimate the full model. The coefficient on EVENT $\times$ TURNOVER $\times$ YIELD_CUM is positive and significant in column $2(15.747, t=3.18)$. Collectively, results suggest that after the reform, investors' dividend tax penalty increases (decreases) for firms with high (low) share turnover during the month before the cum-dividend day. In other words, investors successfully reduce their dividend tax rates by altering their trading behaviors after the reform. This result for the ex-dividend day excess return corroborates a clientele effect examined earlier. Unlike in other studies, the clientele effect in our context is dynamically based on the shareholding period.

\section{Robustness Analyses}

\section{A. Change Analysis}

In this section, we conduct a change analysis to examine whether the change in a firm's dividend payout can be explained by the length of its investors' prereform shareholding period. Such a specification controls for omitted firm characteristics that are time invariant but can affect both the dividend payout and shareholding periods. Our regression model follows that of Lin and Flannery (2013):

$$
\Delta \text { DIVIDEND }_{i, t}=\theta_{0}+\theta_{1} \mathrm{HP}_{\mathrm{PRE}}+\eta \Delta X_{i, t-1}+\varepsilon_{i, t},
$$

where $\triangle$ DIVIDEND denotes the change in a firm's dividend payout from the prereform period to the postreform period. As in Brown et al. (2007), we construct two such alternative measures. The first measure, $\triangle$ YIELD, equals the difference between the current year's dividend yield and the previous year's dividend yield. The second measure, DUMINC, equals 1 if $\triangle$ YIELD is positive, and 0 otherwise. $\mathrm{HP}_{\mathrm{PRE}}$ measures investors' length of holding period before the reform. It is defined as the average daily share turnover during the 1-year period before the reform announcement date (Nov. 16, 2012), multiplied by -1 . As for control variables, we take first differences on all control variables included in equation (5).

Results in Table 6 are consistent with our earlier findings. The positive and significant coefficients on $\mathrm{HP}_{\mathrm{PRE}}$ in both models demonstrate that firms whose individual investors have longer shareholding periods are more likely to increase dividend payouts $(0.027, t=2.03$ for $\triangle$ YIELD; $14.999, z=3.52$ for DUMINC). Hence, our inference remains under this alternative specification.

\section{B. An Alternative Proxy for Individual Investors' Length of Shareholding Periods}

There can be an issue associated with measuring the length of investors' shareholding periods with share turnover (HP). If trading is mostly generated by a small subset of speculative investors, but most shares are held by long-term investors, HP captures investors' holding periods imprecisely. We employ an alternative proxy for the length of individual investors' holding periods to mitigate this concern.

Because publicly listed firms in China are required to disclose semiannually their top 10 investors' ownership, we are able to obtain information on the identities of these investors and their ownership. Such a group typically consists of 
TABLE 6

Robustness Analysis: A Change Specification

Table 6 presents results of the effect of dividend tax reform on firms' dividend policies using a change specification. Following Lin and Flannery (2013), we estimate the following equation:

$$
\Delta \text { DIVIDEND }_{i, t}=\theta_{0}+\theta_{1} \mathrm{HP}_{\mathrm{PRE}}+\eta \Delta X_{i, t-1}+\varepsilon
$$

where $\triangle$ DIVIDEND denotes the change in annual cash dividends from the prereform period to the postreform period. We construct two alternative measures. The first measure, $\triangle Y I E L D$, equals the difference between the current year's dividend yield and the previous year's dividend yield. The second measure, DUMINC, equals 1 if $\triangle$ YIELD is larger than 0 , and 0 otherwise. $\mathrm{HP}_{\mathrm{PRE}}$ is measured as the average daily share turnover in the whole year before the reform announcement date, Nov. 16, 2012, multiplied by -1 . We estimate logistic regressions when the dependent variable is an indicator. All other variables are as defined in Table 1 . The $t$-statistics ( $z$-statistics for logistic regressions) computed with robust standard errors clustered at the firm level are reported in parentheses. ${ }^{*}$, **, and ${ }^{* \star *}$ indicate significance at the $10 \%, 5 \%$, and $1 \%$ levels, respectively.

\begin{tabular}{|c|c|c|}
\hline Variables & $\Delta$ YIELD & DUMINC \\
\hline $\mathrm{HP}_{\mathrm{PRE}}$ & $\begin{array}{l}0.027^{* *} \\
(2.03)\end{array}$ & $\begin{array}{l}14.999^{\star \star \star} \\
(3.52)\end{array}$ \\
\hline$\Delta \ln (\mathrm{MCAP})$ & $\begin{array}{c}0.000 \\
(0.02)\end{array}$ & $\begin{array}{l}-0.633^{\star} \\
(-1.92)\end{array}$ \\
\hline$\Delta \mathrm{LEV}$ & $\begin{array}{l}-0.003 \\
(-1.07)\end{array}$ & $\begin{array}{r}0.341 \\
(0.43)\end{array}$ \\
\hline$\Delta \mathrm{MB}$ & $\begin{array}{l}-0.000^{\star \star \star} \\
(-3.25)\end{array}$ & $\begin{array}{l}-0.164^{\star \star \star} \\
(-3.39)\end{array}$ \\
\hline$\triangle \mathrm{ROE}$ & $\begin{array}{l}0.028^{\star \star \star} \\
(7.69)\end{array}$ & $\begin{array}{l}8.442^{\star \star \star} \\
(5.68)\end{array}$ \\
\hline$\Delta \mathrm{FCF}$ & $\begin{array}{l}-0.001 \\
(-0.87)\end{array}$ & $\begin{array}{l}-0.633^{\star \star} \\
(-2.11)\end{array}$ \\
\hline$\triangle \mathrm{CASH}$ & $\begin{array}{l}0.008^{\star \star \star} \\
(3.25)\end{array}$ & $\begin{array}{l}-0.632 \\
(-0.87)\end{array}$ \\
\hline$\Delta$ VOLATILITY & $\begin{array}{l}0.009^{*} \\
(1.89)\end{array}$ & $\begin{array}{l}4.440^{\star \star \star} \\
(3.20)\end{array}$ \\
\hline$\triangle$ RETURN & $\begin{array}{l}-0.002^{* *} \\
(-2.28)\end{array}$ & $\begin{array}{l}-0.457^{\star} \\
(-1.73)\end{array}$ \\
\hline$\Delta \mathrm{SOE}$ & $\begin{array}{c}0.002 \\
(1.27)\end{array}$ & $\begin{array}{l}0.777^{\star} \\
(1.68)\end{array}$ \\
\hline$\Delta \mathrm{TOP} 1$ & $\begin{array}{l}-0.007 \\
(-1.25)\end{array}$ & $\begin{array}{l}-1.027 \\
(-0.75)\end{array}$ \\
\hline Constant & $\begin{array}{l}-0.003^{*} \\
(-1.75)\end{array}$ & $\begin{array}{l}-0.514 \\
(-1.05)\end{array}$ \\
\hline Industry effects & Yes & Yes \\
\hline $\begin{array}{l}\text { No. of obs. } \\
\text { Adj. } R^{2} / \text { pseudo- } R^{2}\end{array}$ & $\begin{array}{l}1,864 \\
0.069\end{array}$ & $\begin{array}{l}1,864 \\
0.064\end{array}$ \\
\hline
\end{tabular}

both institutional and individual investors. We identify individual investors only and find that they, on average, own a significant percentage of a firm's shares. An average firm has 4.76 individual investors who are also top 10 investors, owning $18.34 \%$ of the firm's shares.

We compute the sum of the absolute change in each individual's ownership from June 30, 2012 to Dec. 31, 2012. We define HP2 as follows:

$$
\mathrm{HP} 2_{i, t}=(-1) \sum_{i=1}^{k}\left|\mathrm{OWN}_{i, t}-\mathrm{OWN}_{i, t-1}\right|,
$$

where $\mathrm{OWN}_{i, t}$ is the percentage of shares held by individual $i$ at time $t \cdot{ }^{21}$ A higher value of HP2 indicates a longer holding period. We then modify

\footnotetext{
${ }^{21}$ We delete firms with seasoned equity offerings during the window over which we measure changes in individual investors' ownership, as seasoned equity offerings lead to mechanical changes in existing investors' ownership. Our results, however, are not sensitive to this adjustment.
} 
equation (5) by replacing HP with our alternative proxy HP2 and rerun the regression. Untabulated results suggest a positive and significant coefficient on the interaction term EVENT $\times$ HP2. Therefore, our key findings are robust to this alternative measure of the length of individual investors' holding period.

\section{Alternative Proxies for Dividend Payout}

In earlier analyses, we rely on a firm's dividend yield as our measure of dividend payout. To establish the robustness of our results, we construct four alternative proxies for dividend payout: DE, DA, INITIATE, and OMIT. DE is constructed as annual cash dividends scaled by net income during the previous fiscal year. ${ }^{22}$ DA is constructed as annual cash dividends scaled by total assets at the previous fiscal year-end. We also consider dividend initiations and dividend omissions. Following Chetty and Saez (2005), we classify a firm as an initiator (INITIATE $=1$ ) if it issues cash dividends in the current year but not in the previous year. Analogously, we define a dividend terminator (OMIT $=1$ ) as a firm that issues cash dividends in the previous year but discontinues it in the current year. INITIATE (OMIT) equals 0 if a firm is not an initiator (terminator). We modify equation (5) by replacing the dependent variable with DE, DA, INITIATE, and OMIT, respectively. Untabulated results show positive and significant coefficients on EVENT $\times$ HP when the dependent variable is DE, DA, or INITIATE, and a negative coefficient on EVENT $\times$ HP when the dependent variable is OMIT. Collectively, empirical results using alternative proxies for dividend payout continue to support our main hypothesis that firms increase their dividend payouts when individual investors' dividend tax rates decrease.

\section{Conclusion}

Employing a recent dividend tax reform in China, we investigate whether individual investors' dividend tax rates shape a firm's payout policy. We find that firms facing a reduction in their individual investors' dividend tax rates are more likely to increase their dividend payouts compared to firms facing an increase in their individual investors' dividend tax rates. Such an effect is concentrated in firms whose controlling shareholders' incentives are more aligned with those of minority shareholders. We further show that investors respond to dividend tax reform by reducing their trading activities during the month before the cumdividend day to lower their dividend tax rates, consistent with a dividend clientele effect. Investors' trading activities successfully reduce their dividend tax rates, as implied by the ex-dividend day stock return patterns before and after the reform.

Our study sheds light on the recent debate over whether tax is a factor shaping firms' dividend policies and adds to a series of studies that investigate firms' dividend policy responses to JGTRRA in the United States (Chetty and Saez (2005), Julio and Ikenberry (2005), Blouin et al. (2011), Edgerton (2013), and Floyd et al. (2015)). The inconclusive evidence on whether firms alter their dividend policies in response to changes in individual investors' tax rates is, at least partially, due to confounding events (e.g., an increasing trend in profitability and

\footnotetext{
${ }^{22}$ We exclude observations with nonpositive net income during the previous fiscal year.
} 
investors' demand for dividends) and/or the importance of institutional investors in the U.S. capital market. Our findings based on a setting where firms are differentially affected and where individual investors are highly likely the marginal investors support the view that when individual investors are of considerable importance, their dividend tax rates affect firms' dividend payouts. In addition, a reduction in investors' trading activities during the month before a firm's cumdividend day and the ensuing reduction in investors' dividend tax penalties directly point to the importance of taxes to investors' wealth.

\section{Appendix. Descriptions of Sample Formation}

In the Appendix, we describe our sample-filtering process. Panel A of Table A1 describes the sample formation for our dividend policy analysis. Panel B describes the sample formation for our investors' trading activities analysis and ex-dividend day stock returns analysis.

TABLE A1

Sample-Filtering Process

Descriptions

No. of Obs.

Panel A. Sample for Dividend Policy Analysis

Obs. of A-share firms in 2012 and 2013

Less: Obs. of firms in the financial industry

Less: Obs. for firms lacking last year's dividend payment information

Less: Obs. with missing values for analysis variables

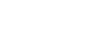

Final sample for dividend policy analysis

Panel B. Sample for Investors' Trading Activities Analysis and Ex-Dividend Day Stock Returns Analysis

Obs. of A-share firms issuing cash dividends in 2012 and 2013

Less: Obs. where the interval between dividend announcement date and cum-dividend day is

\section{References}

Berle, A. A., and G. C. Means. The Modern Corporation and Private Property. New York, NY: Macmillan (1932).

Bertrand, M.; E. Duflo; and S. Mullainathan. "How Much Should We Trust Differences-in-Differences Estimates?" Quarterly Journal of Economics, 119 (2004), 249-275.

Blouin, J.; J. Raedy; and D. Shackelford. "Dividends, Share Repurchases, and Tax Clienteles: Evidence from the 2003 Reductions in Shareholder Taxes." Accounting Review, 86 (2011), 887-914.

Brav, A.; J. R. Graham; C. R. Harvey; and R. Michaely. "Managerial Response to the May 2003 Dividend Tax Cut." Financial Management, 37 (2008), 611-624.

Brown, J. R.; N. Liang; and S. Weisbenner. "Executive Financial Incentives and Payout Policy: Firm Responses to the 2003 Dividend Tax Cut." Journal of Finance, 62 (2007), 1935-1965.

Chetty, R., and E. Saez. "Dividend Taxes and Corporate Behavior: Evidence from the 2003 Dividend Tax Cut." Quarterly Journal of Economics, 120 (2005), 791-833.

Cheung, Y.; P. Rau; and A. Stouraitis. "Tunneling, Propping, and Expropriation: Evidence from Connected Party Transactions in Hong Kong." Journal of Financial Economics, 82 (2006), 343-386. 
Claessens, S.; S. Djankov; J. Fan; and L. Lang. "Disentangling the Incentive and Entrenchment Effects of Large Shareholdings.” Journal of Finance, 57 (2002), 2741-2771.

Del Guercio, D. "The Distorting Effect of the Prudent-Man Laws on Institutional Equity Investments." Journal of Financial Economics, 40 (1996), 31-62.

Desai, M. A., and L. Jin. "Institutional Tax Clienteles and Payout Policy." Journal of Financial Economics, 100 (2011), 68-84.

Dhaliwal, D. S.; M. Erickson; and R. Trezevant. "A Test of the Theory of Tax Clienteles for Dividend Policies.” National Tax Journal, 52 (1999), 179-194.

Dhaliwal, D., and O. Z. Li. "Investor Tax Heterogeneity and Ex-Dividend Day Trading Volume." Journal of Finance, 61 (2006), 463-490.

Dyck, A., and L. Zingales. "Private Benefits of Control: An International Comparison." Journal of Finance, 59 (2004), 537-600.

Edgerton, J. "Four Facts about Dividend Payouts and the 2003 Tax Cut." International Tax and Public Finance, 20 (2013), 769-784.

Elton, E. J., and M. J. Gruber. "Marginal Stockholder Tax Rates and the Clientele Effect." Review of Economics and Statistics, 52 (1970), 68-74.

Faccio, M.; L. H. P. Lang; and L. Young. "Dividends and Expropriation." American Economic Review, 91 (2001), 54-78.

Floyd, E.; N. Li; and D. Skinner. "Payout Policy through the Financial Crisis: The Growth of Repurchases and the Persistence of Dividends." Journal of Financial Economics, 118 (2015), 299-316.

Graham, J. R. "Taxes and Corporate Finance: A Review." Review of Financial Studies, 16 (2003), 1075-1129.

Graham, J. R.; R. Michaely; and M. R. Roberts. "Do Price Discreteness and Transactions Costs Affect Stock Returns? Comparing Ex-Dividend Pricing before and after Decimalization." Journal of Finance, 58 (2003), 2611-2635.

Grinstein, Y., and R. Michaely. "Institutional Holdings and Payout Policy." Journal of Finance, 60 (2005), 1389-1426.

Grossman, S., and O. Hart. "One-Share, One-Vote, and the Market for Corporate Control.” Journal of Financial Economics, 20 (1988), 175-202.

Hanlon, M., and J. Hoopes. "What Do Firms Do When Dividend Tax Rates Change? An Examination of Alternative Payout Response to Dividend Tax Rate Changes." Journal of Financial Economics, 114 (2014), 105-124.

Jacob, M., and M. Jacob. "Taxation, Dividends, and Share Repurchases: Taking Evidence Global." Journal of Financial and Quantitative Analysis, 48 (2013), 1241-1269.

Jensen, M., and W. Meckling. "Theory of the Firm: Managerial Behavior, Agency Costs, and Ownership Structure.” Journal of Financial Economics, 3 (1976), 305-360.

Jiang, G.; C. M. C. Lee; and H. Yue. "Tunneling through Intercorporate Loans: The China Experience." Journal of Financial Economics, 98 (2010), 1-20.

Julio, B., and D. Ikenberry. "Reappearing Dividends." Journal of Applied Corporate Finance, 16 (2005), 89-100.

La Porta, R.; F. Lopez-de-Silanes; and A. Shleifer. "Corporate Ownership around the World.” Journal of Finance, 54 (1999), 471-516.

Li, O. Z., and D. P. Weber. "Taxes and Ex-Dividend Day Returns: Evidence from REITs." National Tax Journal, 62 (2009), 657-676.

Liao, L.; B. Liu; and H. Wang. "China's Secondary Privatization: Perspectives from the Split-Share Structure Reform.” Journal of Financial Economics, 113 (2014), 500-518.

Lie, E., and H. Lie. "The Role of Personal Taxes in Corporate Decisions: An Empirical Analysis of Share Repurchases and Dividends." Journal of Financial and Quantitative Analysis, 34 (1999), 533-552.

Lin, L., and M. J. Flannery. "Do Personal Taxes Affect Capital Structure? Evidence from the 2003 Tax Cut.” Journal of Financial Economics, 109 (2013), 549-565.

Masulis, R.; C. Wang; and F. Xie. “Agency Problems at Dual-Class Companies.” Journal of Finance, 64 (2009), 1697-1727.

Michaely, R.; R. Thaler; and K. Womack. "Price Reactions to Dividend Initiations and Omissions: Overreaction or Drift?” Journal of Finance, 50 (1995), 573-608.

Michaely, R., and J.-L. Vila. "Investors' Heterogeneity, Prices, and Volume around the Ex-Dividend Day." Journal of Financial and Quantitative Analysis, 30 (1995), 171-198.

Michaely, R., and J.-L. Vila. "Trading Volume with Private Valuation: Evidence from the Ex-Dividend Day.” Review of Financial Studies, 9 (1996), 471-509. 
Miller, M. H., and F. Modigliani. "Dividend Policy, Growth, and the Valuation of Shares.” Journal of Business, 34 (1961), 411-433.

Moser, W. "The Effect of Shareholder Taxes on Corporate Payout Choice." Journal of Financial and Quantitative Analysis, 42 (2007), 991-1019.

Perez-Gonzalez, F. "Large Shareholders and Dividends: Evidence from U.S. Tax Reforms" Working Paper, Columbia University (2003).

Shleifer, A., and R. W. Vishny. “A Survey of Corporate Governance.” Journal of Finance, 52 (1997), 737-783. 